Article

\title{
Interpretation of Sustainable Development Using a Set of Macroeconomic and Social Indicators for a Group of Nine Emerging Economies
}

\author{
Olimpia State ${ }^{1}$ (D), Daniel Bulin ${ }^{1,2}$, Iulia Monica Oehler-Sincai ${ }^{2}$, Adrian Lucian Kanovici ${ }^{1}$, \\ Maria Cristina Iorgulescu ${ }^{1, *}$, Claudia Popescu ${ }^{1,3}$ and Delia Popescu ${ }^{1}$ \\ 1 Tourism \& Geography Department, Faculty of Business and Tourism, The Bucharest University of Economic \\ Studies; 030167 Bucharest, Romania; state.olimpia@com.ase.ro (O.S.); daniel.bulin@com.ase.ro (D.B.); \\ adrian.kanovici@rei.ase.ro (A.L.K.); rodica.popescu@rei.ase.ro (C.P.); delia.popescu@com.ase.ro (D.P.) \\ 2 Institute for World Economy, Romanian Academy, 050711 Bucharest, Romania; monica.oehler@iem.ro \\ 3 Institute of Geography, Romanian Academy, 023994 Bucharest, Romania \\ * Correspondence: cristina.iorgulescu@com.ase.ro
}

Received: 20 March 2019; Accepted: 29 May 2019; Published: 31 May 2019

\begin{abstract}
This paper studies the evolution of the most important emerging economies between 2002 and 2017 by estimating their capacity to implement the 2030 Sustainable Development Agenda. In the existing literature there are only a few studies aiming to estimate the capacity of emerging countries to implement the sustainable development goals and demonstrate how groups are performing in the achievement of these goals. Being aware of the strengths and weaknesses of such studies, the authors identified a group of nine countries by applying as the main criterion the size of the economy, reflected by Gross Domestic Product (GDP) in current prices, taking into account the level registered in 2017. From a methodological point of view, the study was conducted through three stages: data collection and processing; empirical analysis and correlation testing; and cluster analysis using Statistica software (10.0, StatSoft, Tulsa OK, USA). The results of this investigation highlighted that all of the nine examined countries have the attributes needed to achieve the Sustainable Development Goals, based on the qualitative and quantitative analysed indicators. Furthermore, the nine countries have already developed measures and adopted national strategies to implement the 2030 Agenda, with political will being also a relevant factor in this regard. This study provides a framework for theoretical and empirical analysis that could also be used in the future, whereby both the number of countries and the timeframe taken into account could be increased in order to identify new development trends for emerging economies.
\end{abstract}

Keywords: sustainable development; emerging economies; 2030 Sustainable Development Agenda; international cooperation; Human Development Index

\section{Introduction}

The 17 Sustainable Development Goals (SDGs), as defined by 2030 Sustainable Development Agenda, are interrelated with each other and cannot be achieved in the absence of sustainable economic growth. Society, the environment, and the economy are grouped into an organic whole [1-4], and the general framework of international relations makes it possible for this ensemble to function sustainably through cooperation, sector-based policies, freer movement of persons, capital, trade flows, technology, and ideas. Even if the SDGs are not legally binding, they have to be included in national frameworks and "translated" to the specific national context [5] according to domestic socio-economic indicators. On one hand, these indicators offer an estimation of a specific country's ability to implement the SDGs, while on the other hand, they reflect particular needs. This article focuses on the analysis of 
the stage and changes through which the most important emerging economies have passed in terms of socio-economic performance by presenting a static image considering four times points separated by equal intervals, namely: 2002, 2007, 2012, and 2017. Nine countries (E9) have been included in the analysis: Saudi Arabia, Argentina, Brazil, China, India, Indonesia, Mexico, Russia, and Turkey (Figure 1), taking into account the economy size criterion reflected by Gross Domestic Product (GDP)in current prices, in dollars (USD) in 2017 (China, second worldwide, after the United States, India sixth, Brazil eighth, Russia 11th, Mexico 15th, Indonesia 16th, Turkey 17th, Saudi Arabia 20th, and Argentina 22nd).

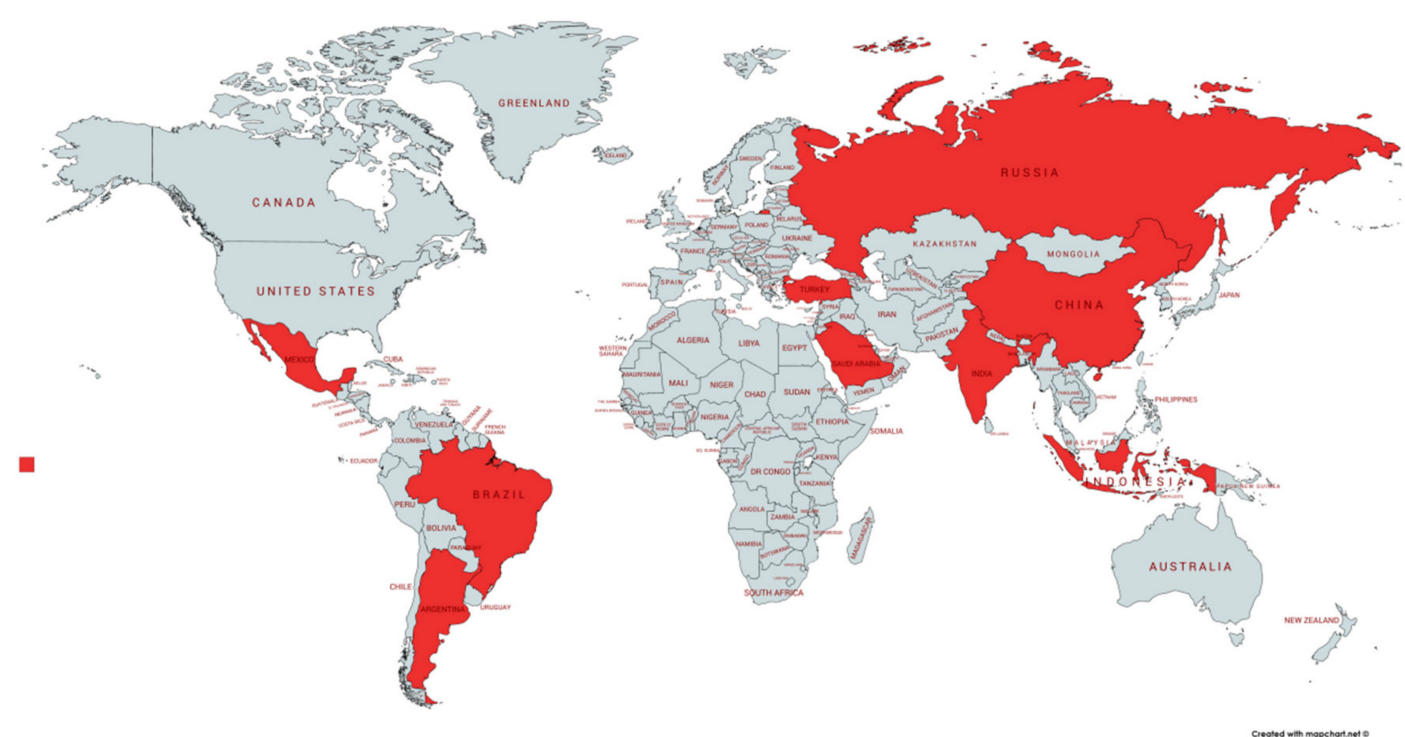

Figure 1. The Emerging 9 (E9) group-representation on the world map. Source: by authors, using mapchart.net application.

The utility and importance of this research are shown by the fact that, by using a set of macroeconomic indicators, one can estimate the ability of the world's countries to implement the 2030 Sustainable Development Agenda adopted during the United Nations (UN) Summit in September 2015.

All the E9 countries included in this analysis are engaged in the global efforts towards sustainable development and have already adopted national strategies aimed at implementing the 2030 Agenda, or at least have made statements in this regard $[6,7]$. Some of them are among the largest greenhouse gas emitters in the world (China, India, Russia, Brazil, and Indonesia) [8]. This is a strong argument about why estimating their capacity to implement the 2030 Sustainable Development Agenda is a useful exercise. We have also assessed the economic potentials of emerging countries (as a necessary condition for the implementation of the SDGs).

\section{Emerging Economies and Sustainable Development}

The United Nations (UN), through the Brundtland report, defined for the first time the concept of sustainable development as the type of development that "meets the needs of the present without compromising the ability of future generations to meet their own needs" [9] (p. 41). Subsequently, many other studies and authors have attempted to extend the scope of this standard definition to identify clear objectives and directions for action, but without reaching a full consensus on a broad definition of this concept. Thus, while some authors have tried to define sustainable development in terms of the objectives to be achieved, other authors have referred to the indicators used to measure it as efficiently as possible or to the values that represent and support sustainable development [10].

Emerging economies are some of the most important international actors that can contribute to the fulfilment of the 17 SDGs defined by the UN in the 2030 Agenda. Thus, although the incentives offered for 
the involvement of emerging countries in the international cooperation process are still low, it is noted that some of them have begun to take concrete steps internally, by signing bilateral or regional agreements [11].

Among the emerging countries, particularly the BRIC states (Brazil, Russia, India, and China) are those that, through their resources and their capacity to coordinate their macroeconomic policies, have the opportunity to decisively influence the global governance process and to advance the steps towards achieving the objectives imposed through the 2030 Agenda for Sustainable Development [12]. On the other hand, some authors have drawn attention to the fact that the BRICs are investing efforts in achieving those objectives that are economically purposeful and which ensure them increased visibility and credibility at the international level. Therefore, their involvement in areas that could lead to improved living standards, as quality of life is reduced, requires greater attention [13].

For China, India, Russia, and Brazil, the economic and financial crisis that began in 2007 in the United States and expanded rapidly worldwide was an opportunity from the perspective of changing the map of economic powers and altering the power distribution in favour of the emerging countries [14]. One of the factors that led to this positive evolution of the emerging economies is the wide range of comparative advantages that they have, especially in economic sectors which produce high added value products [15].

At the same time, Saudi Arabia, Indonesia, Mexico, Argentina, and Turkey are part of the second wave of emerging economies. These countries represent real development poles at the regional level, with increasing international relevance in political and economic terms. Taking into account that the difficulties these countries face are often common ones which cannot be overcome by individual action but only through cross-border international cooperation (the effects of climate change on emerging countries being a good example in this respect), improving cooperation between them would be an opportunity to strengthen their soft power, and also to increase their level of economic development in a sustainable manner [16].

According to the index of overall performance in terms of SDGs [6], the Figure 2 reveals the hierarchy of the E9 countries, where the score signifies a country's position between the worst $(0)$ and the best or target (100) outcomes. Argentina, China, and Brazil have similar positions and they appear as leaders of E9, while Saudi Arabia, Indonesia, and India are the laggards.

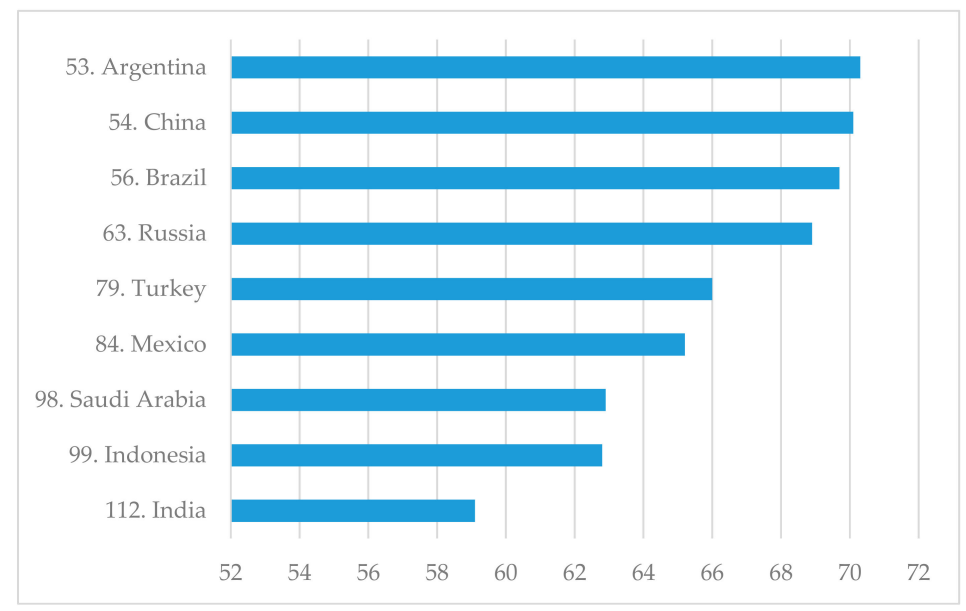

Figure 2. Rankings of the E9 countries with respect to the Sustainable Development Goals (SDGs) index in 2018. Source: [6].

The theory of New Institutional Economics [17-20] underlines that institutions and institutional capacities are crucial for economic, social, and environmental performance. One cannot achieve the SDGs in the absence of good institutions and governance.

Rankings of E9 countries according to the first of the 12 pillars of the Global Competitiveness Index, namely institutions (the other 11 being infrastructure, information and communication technology adoption, macroeconomic stability, health, skills, product market, labour market, financial system, 
market size, business dynamism, and innovation capability) are different than those reflected in Figure 2, which emphasizes that not only good institutions explain good performances (Figure 3). Contrary to the hierarchy indicated by the previous Figure 2, Saudi Arabia, India, and Indonesia are leaders in terms of sound institutions (defined by 20 indicators, including organized crime, terrorism incidence, intellectual property protection, property rights, freedom of the press, shareholder governance, etc.). If these countries have better institutions than Argentina, China, and Brazil for instance, why are they laggards when taking into account the index of overall performance in terms of SDGs? The degree of SDG implementation and indicators related to environment are not criteria taken into account by the World Economic Forum in order to define the quality of institutions.

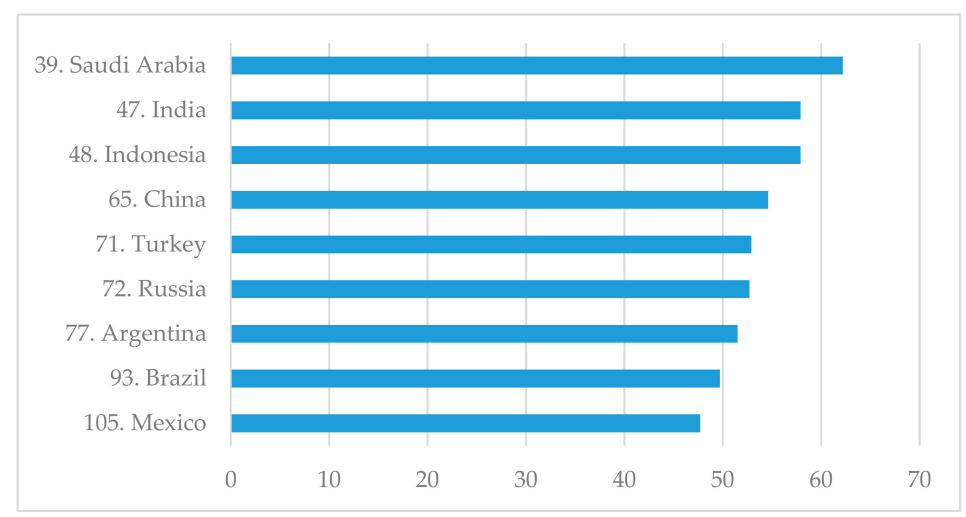

Figure 3. Rankings of the E9 countries according to institutions in 2018. Source: by authors, based on World Economic Forum data [21].

Therefore, even if states cannot achieve the SDGs in the absence of good institutions and governance and institutional capacities are crucial for the successful implementation of the SDGs, there are many other determinants in this regard, motivating a multi-indicator approach.

A simple correlation between the SDG score and the institution score indicates a negative relation $(r=-0.61)$ between these two indicators, as can be seen in the Figure 4 .

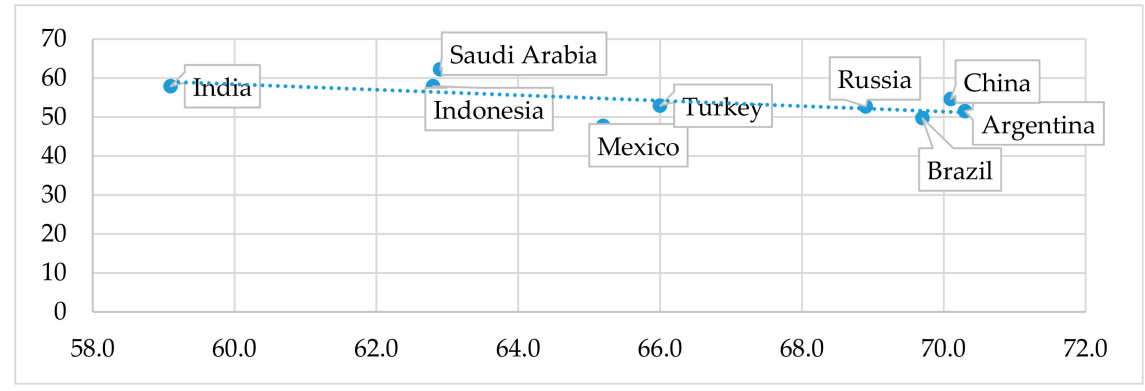

Figure 4. SDG and institutional score correlations. Source: by authors, based on Figure 2 [6] and Figure 3 [21].

If we split the group of analysed countries in three categories, considering the values recorded for the two indicators in the E9, we can observe that only Turkey is in both cases in the "medium score" group, while India and Indonesia score low for SDG, but high for the institutions indicator (Table 1).

Table 1. SDG and institution scores.

\begin{tabular}{ccccc}
\hline \multirow{2}{*}{ Score scale } & \multicolumn{3}{c}{ SDG } & Institutional \\
\cline { 2 - 5 } & Range & Countries & Range & Countries \\
\hline Low score & $59.1-62.8$ & India, Indonesia & $47.7-52.5$ & Mexico, Brazil, Argentina \\
Medium score & $62.81-66.6$ & Mexico, Saudi Arabia, Turkey & $52.5-57.4$ & Russia, Turkey, China \\
High score & $66.61-70.3$ & Argentina, Brazil, China, Russia & $57.4-62.2$ & India, Indonesia, Saudi Arabia \\
\hline \multicolumn{5}{c}{ Source: by authors, based on Figure 2 [6] and Figure 3 [21]. }
\end{tabular}


Furthermore, we have tested the correlation between the subindices components of pillar institutions (Table 2) and the components of public-sector performance assessment (Table 3). As for the SDG-institutions subindices correlation set (Table 2), there is no correlation with security and property rights, and there are respective inverse correlations with the other components, the strongest being with public sector performance.

Table 2. Subindices of the institutions scores.

\begin{tabular}{ccccccc}
\hline Country & Security & $\begin{array}{c}\text { Social } \\
\text { Capital }\end{array}$ & $\begin{array}{c}\text { Checks and } \\
\text { Balances }\end{array}$ & $\begin{array}{c}\text { Public-Sector } \\
\text { Performance }\end{array}$ & Transparency & $\begin{array}{c}\text { Property } \\
\text { Rights }\end{array}$ \\
\hline Argentina & 68.4 & 50.4 & 58.8 & 39.6 & 39 & 45.2 \\
Brazil & 45.8 & 53.6 & 60 & 39.9 & 37 & 48.7 \\
China & 79.1 & 41 & 45.4 & 63.8 & 41 & 59.6 \\
India & 58.7 & 49.5 & 64.2 & 68.5 & 40 & 50.3 \\
Indonesia & 77 & 63 & 55.2 & 56.5 & 37 & 53.5 \\
Mexico & 46 & 45.5 & 51.5 & 48.4 & 29 & 52.7 \\
Russia & 67.9 & 43.9 & 53.2 & 55.3 & 29 & 60 \\
Saudi Arabia & 87.2 & 53.6 & 47.5 & 66.4 & 49 & 57.6 \\
Turkey & 59.6 & 48.2 & 48.4 & 52.5 & 40 & 55.6 \\
Correlation coefficient & -0.086 & -0.414 & -0.233 & -0.631 & -0.26 & 0.001 \\
with SDG score & & & Source: $[21]$. & &
\end{tabular}

The inverse relationship between SDG and the public sector performance is further reflected for three out of the four subindices (with the exception being the E-Participation Index).

Table 3. Subindices of the public-sector performance score.

\begin{tabular}{ccccc}
\hline Country & $\begin{array}{c}\text { Burden of Government } \\
\text { Regulation }\end{array}$ & $\begin{array}{c}\text { Efficiency of Legal Framework } \\
\text { in Settling Disputes }\end{array}$ & $\begin{array}{c}\text { E-Participation } \\
\text { Index }\end{array}$ & $\begin{array}{c}\text { Future Orientation of } \\
\text { Government }\end{array}$ \\
\hline Argentina & 2.5 & 2.7 & 0.62 & 3.5 \\
Brazil & 1.6 & 2.7 & 0.97 & 2.5 \\
China & 4.4 & 4.1 & 0.9 & 4.4 \\
India & 4.5 & 4.5 & 0.96 & 4.7 \\
Indonesia & 4.1 & 4.1 & 0.62 & 3.6 \\
Mexico & 2.7 & 2.8 & 0.94 & 3.9 \\
Russia & 3.3 & 3.5 & 0.92 & 5.4 \\
Saudi Arabia & 4.3 & 4.9 & 0.71 & 3.8 \\
Turkey & 3.3 & 3.3 & 0.86 & -0.626 \\
Correlation coefficient & -0.591 & -0.643 & 0.048 & \\
with SDG score & & & & \\
\hline
\end{tabular}

Source: [21].

Starting from these results, for future research the correlations between the SDGs, the institutional pillar, and the subindices can be tested for developed countries. However, institutional capacity in relation to the implementation of the SDGs is more complex: states have to organize the cooperation across several levels, from the international to the national and regional levels, and also across the different policy fields.

\section{Methodology}

The authors propose as a method of empirical research a statistical analysis based on reliable data provided by international organizations and institutions. The study includes three main stages, as follows:

Stage 1: Collection and processing of data. The statistical data for the nine countries were collected at four time points, 2002, 2007, 2012, and 2017, from international organizations, as follows:

- The Human Development Index (HDI), the United Nations Development Program [22];

- The Global Competitiveness Index (GCI), World Economic Forum [23-26];

- GDP/per capita, real values (USD), International Monetary Fund [27]; 
- Gross capital investment, as a share of GDP, International Monetary Fund [27];

- Savings rate expressed in gross national savings, as a share of GDP, International Monetary Fund [27];

- Unemployment rate, \% of the active population, World Bank [28];

- Budgetary balance (including interest payments on debt), as a share of GDP, International Monetary Fund [27];

- Public debt, as a percentage of GDP, International Monetary Fund [27];

- Current account balance, as a share of GDP, International Monetary Fund [27];

- Structure of GDP formation, calculated according to the added value (the share of the primary, secondary, and tertiary sectors), World Bank [28].

The four years mentioned before have been chosen taking into account the following arguments. Firstly, 2002 was the first year after China's successful accession to the World Trade Organization, which opened a new path for its rise. Secondly, 2007 was the first year of the international economic crisis, which had a different impact on the analysed countries. Thirdly, 2012 can be considered as a post-crisis year and also the end of the commodities super cycle, associated also with deep transformations of the Arab world. Fourthly, 2017 was a year of sustainable growth for most of the emerging economies.

Stage 2: Empirical analysis and correlation testing. The socio-economic indicators were processed and analysed, and further the Pearson (product-moment) correlations were tested and interpreted by taking into consideration the data series for each of the 4 years selected $(2002,2007,2012$, and 2017) (Appendix A).

Stage 3: Cluster analysis. Statistica software was used for defining the main components (HDI, GCI, GDP/capita, investments as a percentage of GDP, saving rate, unemployment rate, budgetary balance as a share of GDP, public debt as a share of GDP, current account balance as a share of GDP, the share of services in GDP formation), data input, data standardization, with the grouping of countries for the four time points based on two techniques:

- Hierarchical clustering method (Ward), based on city-block distances (Manhattan); and

- $\quad$ The k-means method, based on Euclidean distance (Appendix B).

The nine countries are divided into three income categories (considering the gross national income per capita): high (Saudi Arabia and Argentina), medium-high (Brazil, China, Mexico, Russia and Turkey), and medium-low (India and Indonesia) [28]. Their capacity to implement the SDGs depends both on their financial resources and on the institutional capacity and quality of human resources, which imposed the use and analysis of a number of qualitative indicators (in this analysis, the HDI and GCI have been selected).

In the existing literature, there is a limited number of studies on emerging economies from the perspective of SDGs. Most of them refer to a segment of the economy, such as small and medium-sized enterprises [29], or to a metropolitan area of a given country [30]. There are also several studies aiming to estimate the capacity of a country or a group of countries to implement the 2030 Sustainable Development Agenda and the progress in achieving the SDGs. In this regard, the authors of [31] investigated the Sustainable Development Analytical Grid (SDAG), which was developed and tested on Policies, Strategies, Programs and Projects (PSPP) at local and national levels for more than three decades. The SDAG is described as "a coherent framework to assess sustainability of a local project", to compare it "with similar ones" and to connect it with "higher levels of governance". The authors of [32] present a comparative analysis based on reports by the United Nations (the latest version being [4]), Bertelsmann Stiftung [33], Bertelsmann Stiftung and the Sustainable Development Solutions Network [34] and Eurostat [35].This underscores several remarkable conclusions: (1) Sustainability assessment is a difficult task; (2) The strengths and weaknesses of the existing indicators should be taken into account, as these have a major role as policy support instruments; and (3) As the SDGs are "firmly embedded in a policy framework and their operationalization has been mostly done by indicators" and this "approach generates many caveats", "it is absolutely necessary that the expert 
community reach full consensus on the indicator framework and its use". Such a consensus has not been reached until now, and therefore the present paper represents a new exercise coming to complement the current literature.

\section{Empirical Analysis-Macroeconomic and Social Indicators}

\subsection{The Evolution of GDP/Capita}

In 2002, GDP/capita among the E9 countries ranged between US\$492 in India and US\$8823 in Saudi Arabia; the two states remain in extreme positions in each of the following years taken into account in the analysis. Of note is the gradual increase of the difference between the extreme values, from over US $\$ 8000$ in 2002 to US $\$ 15,000$ in 2007 , with a maximum of almost US $\$ 24,000$ achieved in 2012, followed by a decrease to US $\$ 19,000$ in 2017.

Regarding the evolution of GDP/capita for each of the five years taken into account and for the whole period 2002-2017 (Table 4), the following may be stated:

- The highest growth rates were recorded in 2002-2007 for each of the nine countries, with no exceptions;

- The 2007-2012 period was characterized by a decline in growth rates in the nine countries, with China and, partially, India, remaining close to the previous period of time taken into account;

- The evolutions were in contrast between 2012 and 2017: Saudi Arabia, Brazil, Mexico, Russia and, to a lesser extent, Turkey, lowered their GDP per capita, while Argentina and Indonesia increased their GDP per capita by more than 30\% each.

- China experienced the highest growth rate, both at mid-term analysis and throughout the period (+651\%);

- Mexico, ranking second in 2002, was surpassed by Argentina, Russia, and Turkey as a result of registering the lowest growth rates, namely a 9\% drop between 2012 and 2017, with the whole period registering a $25 \%$ advantage.

Table 4. Gross Domestic Product (GDP) per capita in the E9 countries in selected years (real terms and evolution).

\begin{tabular}{ccccccccc}
\hline \multicolumn{3}{c}{ GDP Per Capita, Real Terms, US Dollars } & \multicolumn{5}{c}{ Evolution (\%) } \\
\hline Country & $\mathbf{2 0 0 2}$ & $\mathbf{2 0 0 7}$ & $\mathbf{2 0 1 2}$ & $\mathbf{2 0 1 7}$ & $\mathbf{2 0 0 7 / 2 0 0 2}$ & $\mathbf{2 0 1 2 / 2 0 0 7}$ & $\mathbf{2 0 1 7 / 2 0 1 2}$ & $\mathbf{2 0 1 7 / 2 0 0 2}$ \\
\hline Saudi Arabia & 8823 & 16,667 & 25,208 & 21,096 & 89 & 51 & -16 & 139 \\
Argentina & 2898 & 7316 & 13,890 & 14,463 & 152 & 90 & 4 & 399 \\
Brazil & 2857 & 7369 & 12,369 & 9896 & 158 & 68 & -20 & 246 \\
China & 1150 & 2703 & 6329 & 8643 & 135 & 134 & 37 & 651 \\
India & 492 & 1077 & 1482 & 1976 & 119 & 38 & 33 & 302 \\
Indonesia & 1003 & 2064 & 3745 & 3876 & 106 & 81 & 4 & 286 \\
Mexico & 7466 & 9589 & 10,261 & 9319 & 28 & 7 & -9 & 25 \\
Russia & 2557 & 9755 & 15,411 & 10,956 & 282 & 58 & -29 & 329 \\
Turkey & 3589 & 9563 & 11,553 & 10,537 & 166 & 21 & -9 & 194 \\
\hline
\end{tabular}

Source: [27]. Note: "l"—change rate (\%).

It is noted that, despite the accelerated growth in 2002-2017, India's GDP per capita is less than a quarter of that of China; the Chinese GDP is 4.6 times larger than that of India and the Chinese population still exceeds India's population numerically.

\subsection{Unemployment Rate}

In 2002, the labour market in the E9 countries was confronted with very different situations. There was an unemployment rate of less than 3\% in Mexico, with levels ranging from 4 to $6 \%$ in most cases, but also high unemployment in Russia (8\%), Brazil (9\%), Turkey (10\%), and especially Argentina (almost 20\%). Five years later, unemployment mitigation was in Argentina, highlighted by the decline 
by almost 11 percentage points (p.p.) in five years to $8.5 \%$ of the working population in 2007 , a level similar to the that reported in 2017. For the whole period, besides the particular situation of Argentina, we may notice the decrease in unemployment in Indonesia and Russia, but also the increase of the same indicator in Brazil (+4 p.p. during 2002-2017, +7 p.p. in the last decade) (Table 5).

Table 5. The evolution of unemployment rate (\% of the working population).

\begin{tabular}{ccccccccc}
\hline \multicolumn{3}{c}{ Unemployment Rate (\% of Working Population) } & \multicolumn{3}{c}{ Evolution (Percentage Points) } \\
\hline Country & $\mathbf{2 0 0 2}$ & $\mathbf{2 0 0 7}$ & $\mathbf{2 0 1 2}$ & $\mathbf{2 0 1 7}$ & $\mathbf{2 0 0 7 - 2 0 0 2}$ & $\mathbf{2 0 1 2 - 2 0 0 7}$ & $\mathbf{2 0 1 7 - 2 0 1 2}$ & $\mathbf{2 0 1 7 - 2 0 0 2}$ \\
\hline Saudi & 5.27 & 5.73 & 5.52 & 5.523 & 0.46 & -0.21 & 0.01 & 0.25 \\
Arabia & & & & & & & & \\
Argentina & 19.59 & 8.47 & 7.22 & 8.518 & -11.12 & -1.25 & 1.30 & -11.07 \\
Brazil & 9.11 & 8.09 & 7.19 & 13.32 & -1.02 & -0.90 & 6.13 & 4.21 \\
China & 4.41 & 3.76 & 4.47 & 4.675 & -0.65 & 0.71 & 0.21 & 0.26 \\
India & 4.432 & 4.06 & 3.621 & 3.523 & -0.37 & -0.44 & -0.09 & -0.91 \\
Indonesia & 6.34 & 8.06 & 4.47 & 4.18 & 1.72 & -3.59 & -0.29 & -2.16 \\
Mexico & 2.87 & 3.65 & 4.92 & 3.42 & 0.78 & 1.27 & -1.50 & 0.55 \\
Russia & 7.92 & 6.1 & 5.44 & 5.2 & -1.82 & -0.66 & -0.24 & -2.72 \\
Turkey & 10.36 & 8.87 & 8.15 & 11.263 & -1.49 & -0.72 & 3.11 & 0.90 \\
\hline
\end{tabular}

Source: [28]. Note: “-"—difference (percentage points).

In India, there was a gradual decrease in the unemployment rate, but this indicator is distorted by the fact that, based on social aid schemes, a large proportion of the population is considered to be employed, although the correct term would be socially assisted [36].

\subsection{Economic Structure by Sectors}

Regarding the structure of the E9 economies by sectors in 2002, according to their share in the added value (Figure 5), the existence of three particular situations can be determined:

- There was a major share of industry in Saudi Arabia, China, and Indonesia;

- There was an important role played by the agricultural sector in India (one-fifth of GDP), Indonesia, China, Argentina, and Turkey (more than 10\%), while in Mexico, Russia, Brazil or Saudi Arabia the primary sector recorded only $3-6 \%$ of GDP;

- The share of services ranged between $40 \%$ in Indonesia and China up to almost $60 \%$ in Mexico and Brazil.

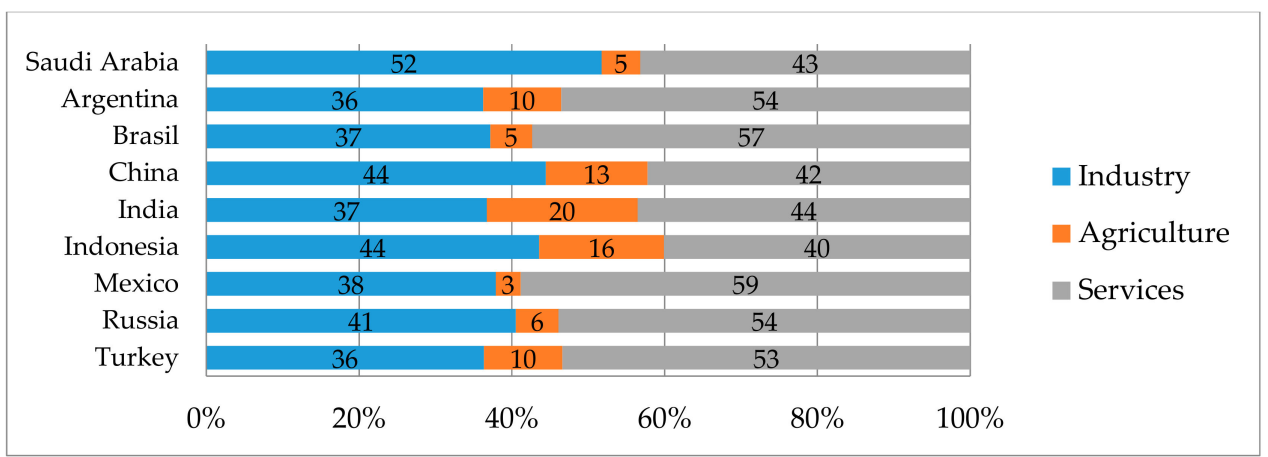

Figure 5. Structure of the economy, by sector, in 2002 (\% of gross added value). Source: by authors, based on World Bank data [28].

Five years later, a number of structural changes in GDP formation may be noted (Figure 6):

- $\quad$ Significant increases were found in the share of industry in the economy of Saudi Arabia (+11 p.p.), Argentina (+7 p.p.), and Russia (+5 p.p.), simultaneously with a slight decrease in importance of the tertiary sector in these countries; 
- A decreasing share of the agricultural sector was seen in almost all E9 countries, by up to 3 p.p. in Argentina, China and India;

- Although the share of the tertiary sector in most of the E9 economies remained high, the service sector did not significantly increase over the period 2002-2007.

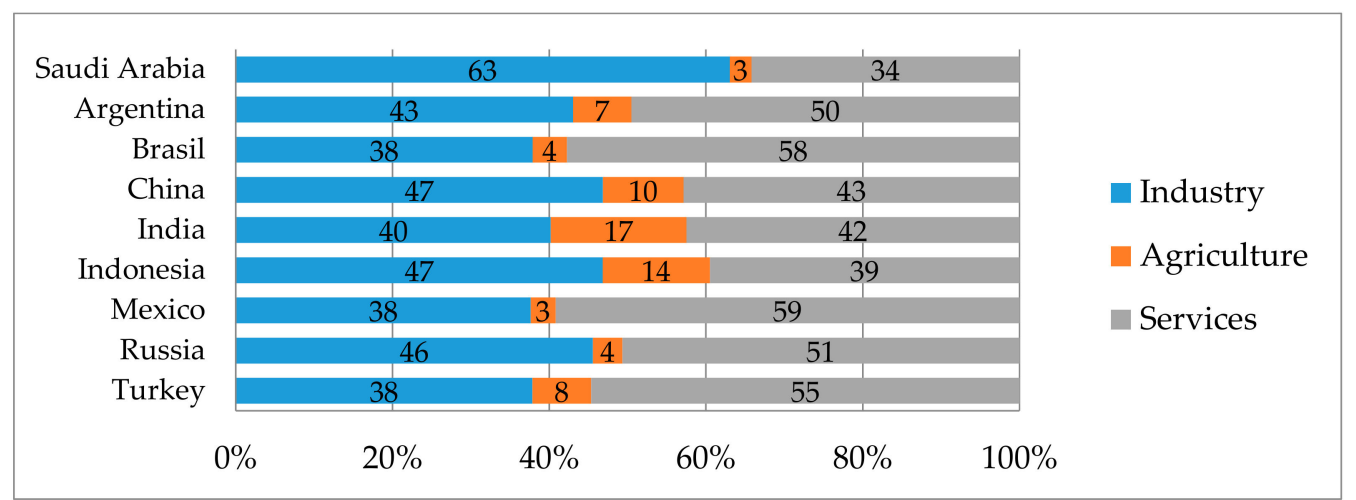

Figure 6. Structure of the economy, by sector, in 2007 (\% of gross added value). Source: by authors, based on World Bank data [28].

The period 2007-2012 was characterized by several developments regarding the contribution of economic sector to the formation of GDP (Figure 7). There was a decreasing share of the industrial sector (by up to 3 p.p.) in India and Russia. The role of the agricultural sector was maintained, with shares that were still significant in India and Indonesia and less significant in China and Turkey. The share of services in relation to GDP increased by up to 4 p.p. in Argentina and India.

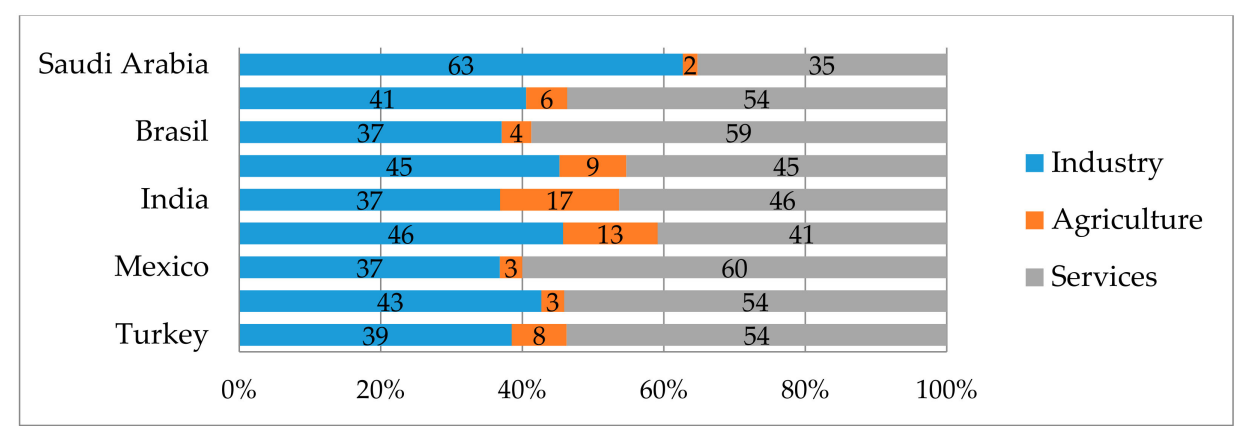

Figure 7. Structure of the economy, by sector, in 2012 (\% of gross added value). Source: by authors, based on World Bank data [28].

From 2012 to 2017, the previously highlighted trends were confirmed. The accelerated development is noticeable in some particular situations:

- There was a decline in the share of the industrial sector, by almost 20 percentage points in Saudi Arabia and 5 percentage points in China, along with an increase of the services sector;

- There were significant increases in the tertiary sector, by 17 percentage points in Saudi Arabia, 7 p.p. in China, and 4 p.p. in Brazil (with this country reaching the maximum in the group, with a $63 \%$ contribution of services in the total gross added value).

At the end of 2017, with no exceptions, the services sector generated the largest share of added value in GDP (Figure 8), with this level accounting for less than 50\% only in India and Indonesia. The situation is explained by the still significant share of agriculture in the economy ( $13 \%$ in Indonesia and $15 \%$ in India). 


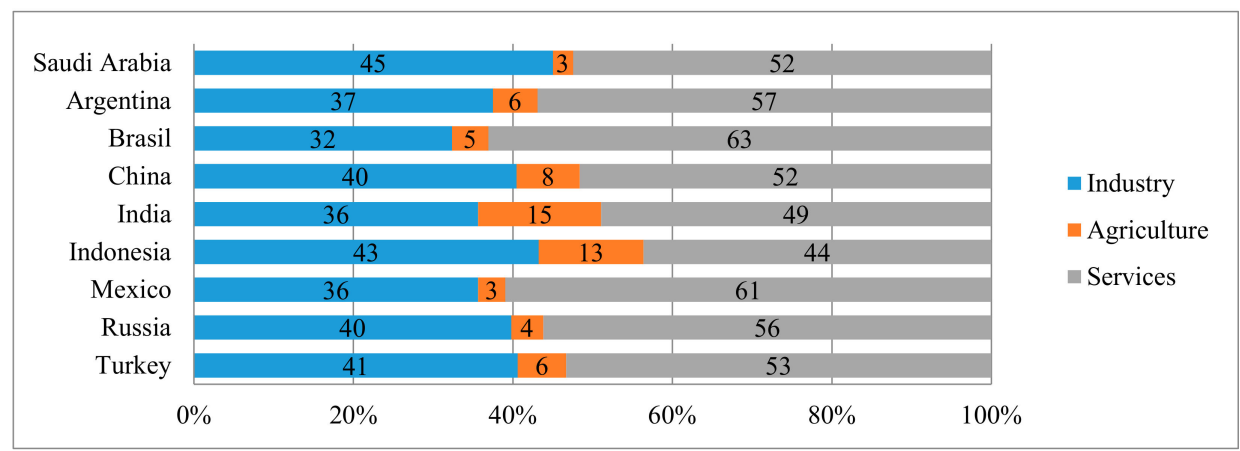

Figure 8. Structure of the economy, by sector, in 2017 (\% of gross added value). Source: by authors, based on World Bank data [28].4.4. Public Debt and Budget Balance.

The diversity of the economies of the E9 countries is also confirmed by the main indicators of public finance assessment: public debt and budget balance (Figure 9), both in terms of GDP.

Concerning public debt (Table 6), an overview of the situation of the nine countries at the selected time points reveals a number of particular aspects:

- The drastic reduction of Saudi Arabia's debt, from almost 100\% of GDP in 2002 to $17 \%$ of GDP in 2017, with the same situation being encountered to a lesser extent in Russia (from 37\% to $16 \%$ in 2002-2017);

- Argentina's recovery from this point of view: if in 2002 the debt level was 1.5 times higher than the country's GDP, five years later it reached about $60 \%$, close to the level reported in 2017;

- The oscillating evolution of Brazil's public debt, for which a decrease was seen from $80 \%$ of GDP to almost $60 \%$ of GDP in the period 2002-2012; this has been virtually cancelled out by developments over the past 5 years;

- The sustainable level reached by the economies of Indonesia and Turkey, countries which reduced their public debt by $50 \%$ over the past 15 years, to less than $30 \%$ of GDP;

- The increase in public debt in China and Mexico.

In the case of India, there was a downward trend of public debt as a share of GDP between 2002 and 2012, but it increased slightly in 2017 (to 71\%) as compared to 2012 (69\%).

Table 6. Public debt in E9 countries in selected years (\% of GDP).

\begin{tabular}{ccccc}
\hline Country/Year & $\mathbf{2 0 0 2}$ & $\mathbf{2 0 0 7}$ & $\mathbf{2 0 1 2}$ & $\mathbf{2 0 1 7}$ \\
\hline Saudi Arabia & 96 & 17 & 3 & 17 \\
Argentina & 152 & 61 & 39 & 58 \\
Brazil & 79 & 64 & 62 & 84 \\
China & 26 & 29 & 34 & 47 \\
India & 83 & 74 & 69 & 71 \\
Indonesia & 62 & 32 & 23 & 29 \\
Mexico & 42 & 37 & 43 & 54 \\
Russia & 37 & 8 & 12 & 16 \\
Turkey & 72 & 38 & 33 & 28 \\
\hline \multicolumn{5}{c}{ Source: [27]. }
\end{tabular}

In 2002, only three of the nine countries registered budget deficits-Saudi Arabia and China, each within $3 \%$ of GDP, and India $6.1 \%$ of GDP. Afterward the levels have been intensely oscillating and underscored extremely diverse situations, the particular features of the E9 being as follows:

- In 2007, none of the countries included in the analysis had budget deficits, ten years later only Mexico reported a surplus. Of the eight countries registering a deficit in 2017, only Saudi Arabia and Argentina exceeded the 3\% threshold, if it is agreed that this threshold could be sustainable for emerging countries. 
- Saudi Arabia is also a unique and particular case: in 2007 and 2012, it reported budget surpluses of over 10\%, but in 2017 its deficit was the largest among the $\mathrm{E} 9$ countries, as a direct consequence of the evolution of crude oil prices, given that Saudi Arabia is the world's largest exporter of crude oil.

- Brazil's evolution is also distinct, as its budget surplus has been diminishing constantly since 2002 due to commodity price developments, which led to deficits starting in 2015 and continuing in the long run [27].

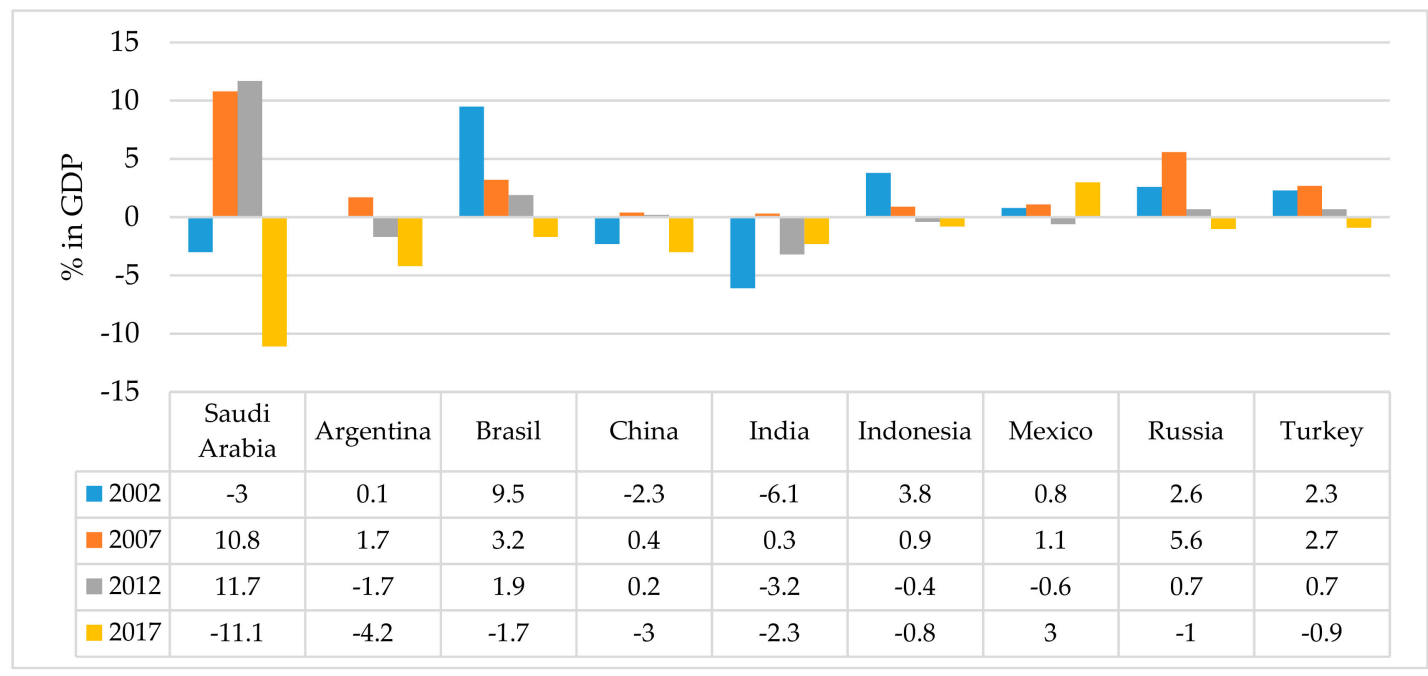

Figure 9. Budget balance in E9 countries in selected years (\% of GDP). Source: by authors, based on International Monetary Fund data [27].

\subsection{Current Account Balance}

A glance at the current account balance and its evolution (Table 7) shows that in 2002, three of the nine countries recorded a deficit (Brazil, Mexico, and Turkey), even if the share in GDP was at a low of less than $2 \%$.

Table 7. Current account balance in E9 countries in selected years (\% of GDP).

\begin{tabular}{ccccc}
\hline Country/Year & $\mathbf{2 0 0 2}$ & $\mathbf{2 0 0 7}$ & $\mathbf{2 0 1 2}$ & $\mathbf{2 0 1 7}$ \\
\hline Saudi Arabia & 6.262 & 22.472 & 22.387 & 2.218 \\
Argentina & 7.929 & 2.1 & -0.369 & -4.913 \\
Brazil & -1.59 & 0.029 & -3.012 & -0.475 \\
China & 2.397 & 9.889 & 2.513 & 1.372 \\
India & 1.211 & -1.27 & -4.806 & -1.87 \\
Indonesia & 3.676 & 1.445 & -2.657 & -1.706 \\
Mexico & -1.726 & -0.959 & -1.546 & -1.681 \\
Russia & 7.401 & 5.17 & 3.225 & 2.246 \\
Turkey & -0.263 & -5.474 & -5.49 & -5.571 \\
\hline \multicolumn{5}{c}{ Source: [27]. }
\end{tabular}

Five years later, Turkey reported a current account deficit of over five percent of GDP, a level also attained in 2012 and 2017, respectively. Another particular situation is that of India, which had liabilities between 2002 and 2007 and recorded a worse situation in 2012 (5\% of GDP), but recovered afterwards (below $2 \%$ of GDP in 2017). In 2017, six of the nine states recorded a current account deficit, with some of them (Argentina and Turkey) with a higher level, around 5\% of GDP (Table 5).

\subsection{The Role of Savings and Investments}

In 2002, the share of gross capital investment in E9 countries' GDP was between 10.3\% in Argentina and $36.9 \%$ of GDP in China. Even for the next years taken into account in the analysis, 
China distinguishes itself by having the largest share of investments in GDP, ranging from $40 \%$ to $50 \%$. It is also worth mentioning the growth trend of E9 countries' investments between 2007 and 2017, especially during the first half of the period. Over the whole period, except for Brazil, all E9 countries increased their share of gross capital investment, the record being held by Turkey, with an increase up to 10 p.p. (Table 8).

Table 8. Gross capital investments and gross national savings in the E9 countries in selected years (\% of GDP).

\begin{tabular}{|c|c|c|c|c|c|c|c|c|}
\hline \multirow{2}{*}{ Country } & \multicolumn{4}{|c|}{ Investments, $\%$ of GDP } & \multicolumn{4}{|c|}{ Gross National Savings, $\%$ of GDP } \\
\hline & 2002 & 2007 & 2012 & 2017 & 2002 & 2007 & 2012 & 2017 \\
\hline $\begin{array}{l}\text { Saudi } \\
\text { Arabia }\end{array}$ & 19.7 & 26.5 & 26.5 & 27.9 & 26.0 & 48.9 & 48.9 & 30.1 \\
\hline Argentina & 10.3 & 20.1 & 16.5 & 18.6 & 18.7 & 22.8 & 16.8 & 17.6 \\
\hline Brazil & 17.6 & 19.8 & 21.5 & 15.5 & 16.0 & 19.8 & 18.5 & 15.0 \\
\hline China & 36.9 & 41.2 & 47.2 & 44.4 & 39.3 & 51.1 & 49.7 & 45.8 \\
\hline India & 24.8 & 38.1 & 38.3 & 30.6 & 26.0 & 36.8 & 33.5 & 28.8 \\
\hline Indonesia & 24.2 & 28.7 & 35.1 & 33.4 & 23.4 & 24.4 & 32.4 & 31.7 \\
\hline Mexico & 20.7 & 23.1 & 23.9 & 23.1 & 19.0 & 22.2 & 22.3 & 21.4 \\
\hline Russia & 19.4 & 24.1 & 24.5 & 24.3 & 26.8 & 29.3 & 27.8 & 26.5 \\
\hline Turkey & 21.2 & 28.7 & 28.3 & 31.0 & 21.7 & 23.3 & 22.8 & 25.5 \\
\hline
\end{tabular}

With respect to the saving rate (expressed as a share of the gross national savings in GDP), presented in the table above, it is noted that:

- The 2002-2007 period was characterized by the increase in the share for all E9 countries, without exception, with a noticeable pace in the increase for Saudi Arabia (+13 p.p.), China (+11 p.p.), and India (+10 p.p.).

- Five years later, in 2012, in most of the E9 countries the share of savings in GDP experienced a slight decrease, with the exception of Indonesia, which increased its level by 8 p.p.; Saudi Arabia and China were, as in 2007 , in the top two positions, with a savings rate of about $50 \%$.

- The latest data, for 2017, show a continuation of the new decreasing trend (except for Turkey), especially a sharp decline in Saudi Arabia, from $49 \%$ to $30 \%$ of GDP.

With regard to the second largest emerging economy worldwide, Table 5 highlights that India has high levels of investment and saving rates as a share of GDP, at about $31 \%$ and $29 \%$, respectively. As far as the first indicator is concerned, India is outrun by China, Indonesia, and Turkey, while considering the second indicator, it is surpassed by China, Indonesia, and Saudi Arabia.

\subsection{Qualitative Indicators}

The Global Competitiveness Index (GCI) assesses the competitiveness of economies based on decisive factors in characterizing the domestic and international business environment (Table 9). The world ranking in 2017 included 137 countries. In the world hierarchy, China ranked 27th, Saudi Arabia ranked 30th, Indonesia 36th, Russia 38th, India 40th, Mexico 51th, Turkey 53rd, Brazil 80th, and Argentina 92nd.

In the E9 group, in 2017, the most competitive economy was China, followed by Saudi Arabia. In fact, the two countries have switched between the first two positions as compared to 2012, with positions they have occupied in previous years as well regardless of the calculation methodology developed by the World Economic Forum. Remarkable development over the past 15 years was found in Indonesia. This country's economy is rated the third among the nine E9 states. In contrary, Mexico's economy was ranked third in the group in 2002, but only sixth in 2017, while Brazil's economy, in the fourth position in 2002, was ranked the second to last in 2017, with both economies losing competitiveness in recent years. 
Table 9. Global Competitiveness Index (GCI; scores and rankings in the E9).

\begin{tabular}{cccccccccc}
\hline GCI & \multicolumn{2}{c}{$\mathbf{2 0 1 7}$} & \multicolumn{2}{c}{$\mathbf{2 0 1 2}$} & \multicolumn{2}{c}{$\mathbf{2 0 0 7}$} & \multicolumn{2}{c}{2002} \\
\hline Countries & Score & $\#$ & Score & $\#$ & Score & $\#$ & Score & $\#$ \\
\hline China & 5.00 & 1 & 4.83 & 2 & 4.70 & 2 & 4.37 & 2 \\
Saudi & 4.83 & 2 & 5.19 & 1 & 4.72 & 1 & 4.50 & 1 \\
Arabia & 4.68 & 3 & 4.40 & $4-5$ & 4.25 & $5-6$ & 3.36 & 8 \\
Indonesia & 4.64 & 4 & 4.20 & 8 & 4.25 & $5-6$ & 3.64 & 7 \\
Russia & 4.59 & 5 & 4.32 & 7 & 4.31 & 3 & 4.03 & 5 \\
India & 4.44 & 6 & 4.36 & 6 & 4.23 & 7 & 4.11 & 3 \\
Mexico & 4.42 & 7 & 4.45 & 3 & 4.15 & 8 & 3.31 & 9 \\
Turkey & 4.14 & 8 & 4.40 & $4-5$ & 4.28 & 4 & 4.09 & 4 \\
Brazil & 3.95 & 9 & 3.87 & 9 & 3.76 & 9 & 3.66 & 6 \\
Argentina & & & Source: $[23-26]$. & & & &
\end{tabular}

Another relevant index is the Human Development Index (HDI), an indicator of life expectancy, literacy, access to education, and living standards, used to compare the levels of development worldwide. The 2017 ranking took into account 189 countries; the analysed countries ranked as follows: Saudi Arabia 39th, Argentina 47th, Russia 49th, Turkey 64th, Mexico 74th, Brazil 79th, China 86th, Indonesia 116th, and India 130th. According to the most recent report [22], Saudi Arabia, Argentina, and Russia have the highest values of human development among the emerging countries, while China, Indonesia, and India are ranked in the last positions (Table 10).

Table 10. Human Development Index (scores and rankings of the E9).

\begin{tabular}{|c|c|c|c|c|c|c|c|c|}
\hline HDI & \multicolumn{2}{|c|}{2017} & \multicolumn{2}{|c|}{2012} & \multicolumn{2}{|c|}{2007} & \multicolumn{2}{|c|}{2002} \\
\hline Countries & Score & $\#$ & Score & $\#$ & Score & \# & Score & \# \\
\hline $\begin{array}{l}\text { Saudi } \\
\text { Arabia }\end{array}$ & 0.853 & 1 & 0.835 & 1 & 0.783 & 2 & 0.748 & 2 \\
\hline Argentina & 0.825 & 2 & 0.818 & 2 & 0.792 & 1 & 0.769 & 1 \\
\hline Russia & 0.816 & 3 & 0.798 & 3 & 0.767 & 3 & 0.732 & 3 \\
\hline Turkey & 0.791 & 4 & 0.76 & 4 & 0.708 & 5 & 0.672 & 6 \\
\hline Mexico & 0.774 & 5 & 0.757 & 5 & 0.739 & 4 & 0.71 & 4 \\
\hline Brazil & 0.759 & 6 & 0.736 & 6 & 0.705 & 6 & 0.698 & 5 \\
\hline China & 0.752 & 7 & 0.722 & 7 & 0.675 & 7 & 0.611 & 8 \\
\hline Indonesia & 0.694 & 8 & 0.675 & 8 & 0.642 & 8 & 0.618 & 7 \\
\hline India & 0.64 & 9 & 0.6 & 9 & 0.556 & 9 & 0.504 & 9 \\
\hline
\end{tabular}

Source: [22]. HDI: Human Development Index.

It can be noted that there were no major changes in the HDI E9 rankings, even after longer periods of time; it should be also noted that, after 2010, a number of changes occurred in its calculation methodology which, moreover, can partially justify particular developments, such as the switch between Saudi Arabia and Argentina for the first position or Turkey's score improvement. It is worth noting that all the nine countries have experienced continuous progress in their level of human development over the whole period.

\section{Correlation Testing and Cluster Analysis}

After testing the product-moment correlations (Pearson) between the indicators included in the analysis, for the 2002 data, one can state the following:

- There is a strong and direct relationship between the global competitiveness index and the share of investments in GDP $(r=0.83)$, along with a positive and very strong association between the Global Competitiveness Index and the share of gross national savings in GDP $(r=0.90)$; 
- There is a very strong and direct relationship between the human development index and GDP per capita $(\mathrm{r}=0.93)$;

- There is an indirect relationship between GDP per capita and the share of the budget balance $(\mathrm{r}=$ $-0.69)$;

- There is an extremely strong and direct relationship between the share of investments in GDP and the share of gross national savings in GDP $(r=0.96)$;

- There is a negative relationship between the share of investments in GDP and the share of services in GDP formation $(\mathrm{r}=-0.71)$.

The correlation testing for 2007 data reveals the existence of a greater number of direct and indirect associations between indicators, as follows:

- A strong and direct relationship between the global competitiveness index and the share of gross national savings in GDP $(r=0.82)$, along with a relationship of a lower intensity between competitiveness and the current account balance $(r=0.68)$;

- A positive and strong association between the human development index and the GDP per capita $(r=0.70)$, and a negative relationship between HDI and the share of investments in GDP $(r=$ $-0.70)$;

- A positive and strong relationship between GDP per capita and budget balance $(\mathrm{r}=0.86)$;

- A close relationship between the share of investments in GDP and the share of gross national savings in GDP $(r=0.69)$;

- A strong direct relationship between the share of gross national savings in GDP and the current account balance $(r=0.69)$, together with an indirect relationship between the share of savings and the contribution of services to GDP formation $(r=-0.69)$.

Further, 2012 marked a decrease in the number of associations between the variables used in the analysis:

- A strong positive relationship between the share of investments in GDP and the share of gross national savings in GDP $(r=0.84)$;

- A positive relationship between the unemployment rate and the share of public debt $(r=0.77)$, with that being the first time such an association was found between the two variables;

- Two indirect relationships between the share of investments in GDP, on one hand, and the unemployment rate $(r=-0.69)$, respectively, with the share of public debt $(r=-0.73)$, on the other hand;

- The last year taken into account in the analysis, 2017, confirmed the series of correlations between the variables, which can be found in previous years as well;

- Strong associations between the competitiveness index, on one hand, and the share of gross national savings in GDP $(r=0.83)$, the budget balance as a percentage of GDP $(r=0.78)$, and the current account balance as a share of GDP $(r=0.71)$, on the other hand;

- A very strong relationship between HDI and the value of GDP per capita $(r=0.90)$;

- A strong direct association between GDP per capita and the budget balance $(r=0.83)$, respectively, and the current account balance $(r=0.79)$;

- A direct relationship between the share of investments and gross national savings in GDP $(r=$ 0.72 ), and a very strong relationship between the budget balance and the current account balance $(\mathrm{r}=0.9)$;

- Indirect relationships between the share of services in GDP and the share of gross national savings in GDP $(r=-0.82)$, and the current account balance and the share of public debt $(r=$ $-0.69)$, respectively.

The socio-economic indicators previously analysed have shown the heterogeneity of the E9 group, and the results of the cluster analysis (hierarchical, Ward method, City-Block distances) come to confirm this situation. 
Looking at the dendrogram (Figure 10) for the four moments in time, with an arbitrary choice of linkage distance of 10 , one can state the following:

- There is an existence of five well-defined groups of countries in 2002; five groups were also found in 2017, with differences in their structure. The cluster formed by Turkey, Russia, and Indonesia disappeared, with each of these countries approaching other countries in terms of the criteria selected-with Turkey approaching Argentina, Russia to Saudi Arabia, and Indonesia to India. Moreover, China has also distanced itself from the other countries, now forming the only "one-country" cluster;

- The existence of two large blocks in 2007 and 2012. In 2012, block 1 (left) was an extremely heterogeneous one, comprising six of the nine countries-if the agreed distance is halved to 5 , the group "breaks" completely, Turkey and Brazil are the most similar economies in terms of the indicators included in the analysis; in 2012 the situation was not changed fundamentally, with only Indonesia's proximity to India being of note, a phenomenon that continued in the following years.
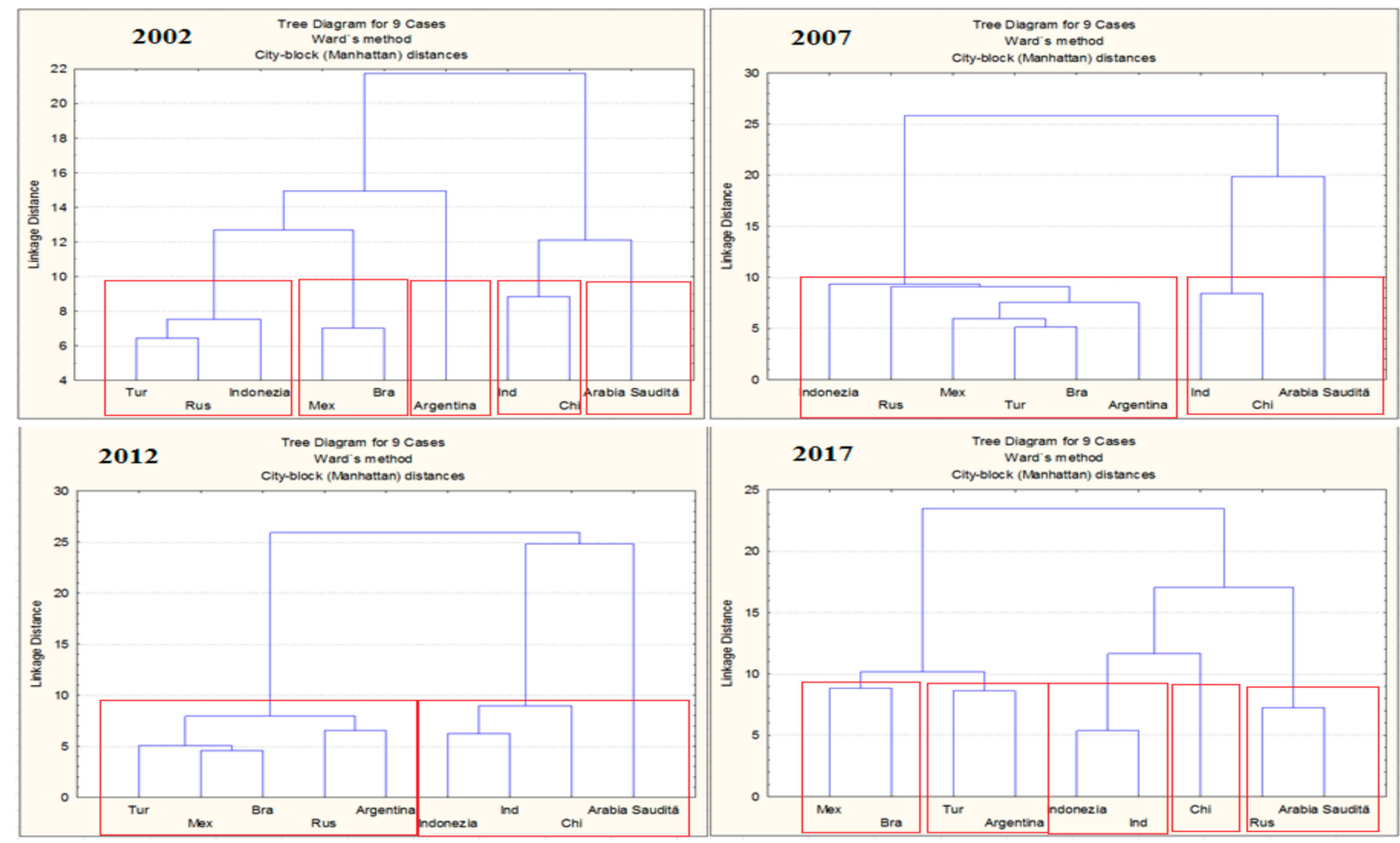

Figure 10. Dendrogram cluster analysis in 2002, 2007, 2012, and 2017. Source: results obtained with Statistica software.

For a deeper analysis of the common features and differences between the E9 countries, a cluster analysis with a different method has been conducted, with k-means (Euclidean distances) setting the number of clusters on the basis of the previous results. Table 11 synthesizes and highlights the characteristics of each cluster, with the common elements that defined, at that specific time, the economies of the countries in its structure. 
Table 11. Cluster structure and characteristics (using the k-means method).

\begin{tabular}{|c|c|c|c|c|}
\hline Cluster & 2002 & Characteristics & 2007 & Characteristics \\
\hline$\# 1$ & Argentina & $\begin{array}{l}\text { Very low Competitiveness Index } \\
\text { (GCI), high Human Development } \\
\text { Index (HDI), Low investments, } \\
\text { positive current account balance, } \\
\text { extremely high public debt, high } \\
\text { \% of services } \\
\text { Extremely high unemployment } \\
\text { rate }\end{array}$ & Saudi Arabia & $\begin{array}{l}\text { Very high GDP/capita, low \% of } \\
\text { services, low public debt } \\
\text { A significant positive current } \\
\text { account balance, high budget } \\
\text { surplus, high savings, high GCI } \\
\text { and HDI }\end{array}$ \\
\hline$\# 2$ & $\begin{array}{l}\text { Indonesia } \\
\text { Russia } \\
\text { Turkey }\end{array}$ & $\begin{array}{l}\text { High unemployment rate, average } \\
\% \text { of services, budget surplus, } \\
\text { Low GCI }\end{array}$ & $\begin{array}{l}\text { Indonesia } \\
\text { India }\end{array}$ & $\begin{array}{l}\text { Low GDP/capita, low \% of } \\
\text { services, high public debt, } \\
\text { Low HDI }\end{array}$ \\
\hline$\# 3$ & $\begin{array}{l}\text { China } \\
\text { India }\end{array}$ & $\begin{array}{l}\text { Low HDI, positive current } \\
\text { account balance, average \% of } \\
\text { services, low unemployment rate, } \\
\text { low Gross Domestic Product } \\
\text { (GDP)/capita }\end{array}$ & China & $\begin{array}{l}\text { High GCI, low HDI, high savings, } \\
\text { high investments, high current } \\
\text { account balance, low public debt, } \\
\text { low \% of services, low } \\
\text { unemployment rate, low } \\
\text { GDP/capita }\end{array}$ \\
\hline$\# 4$ & Saudi Arabia & $\begin{array}{l}\text { Very high GDP/capita, low \% of } \\
\text { services, high public debt, positive } \\
\text { current account balance, budget } \\
\text { deficit, high GCI and HDI }\end{array}$ & $\begin{array}{l}\text { Mexico } \\
\text { Russia }\end{array}$ & $\begin{array}{l}\text { High GDP/capita, sustainable } \\
\text { public debt, budget surplus, } \\
\text { average investments, relatively } \\
\text { low GCI, } \\
\text { Relatively high HDI }\end{array}$ \\
\hline$\# 5$ & $\begin{array}{c}\text { Brazil } \\
\text { Mexico }\end{array}$ & $\begin{array}{l}\text { High \% of services, negative } \\
\text { current account balance, low } \\
\text { savings, average HDI and GCI }\end{array}$ & $\begin{array}{l}\text { Argentina } \\
\text { Brazil } \\
\text { Turkey }\end{array}$ & $\begin{array}{l}\text { Average-high GDP/capita, high } \\
\text { unemployment rate, average \% of } \\
\text { services, budget surplus, low } \\
\text { savings }\end{array}$ \\
\hline Cluster & 2012 & Characteristics & 2017 & Characteristics \\
\hline$\# 1$ & $\begin{array}{c}\text { Mexico } \\
\text { Russia }\end{array}$ & $\begin{array}{l}\text { High GDP/capita, sustainable } \\
\text { public debt, budget surplus, } \\
\text { relatively low investments and } \\
\text { savings, relatively low GCI }\end{array}$ & Saudi Arabia & $\begin{array}{l}\text { Very high GDP/capita, average \% } \\
\text { of services, low public debt, } \\
\text { Negative current account balance, } \\
\text { budget surplus, } \\
\text { High GCI and HDI }\end{array}$ \\
\hline$\# 2$ & Saudi Arabia & $\begin{array}{l}\text { Very high GDP/capita, low \% of } \\
\text { services, extremely low public } \\
\text { debt, high positive current } \\
\text { account balance, high budget } \\
\text { surplus, high gross national } \\
\text { savings, high HDI and GCI }\end{array}$ & $\begin{array}{c}\text { Argentina } \\
\text { Brazil }\end{array}$ & $\begin{array}{l}\text { Very low GCI, low \% of } \\
\text { investments } \\
\text { Low \% of savings, negative } \\
\text { current account balance, budget } \\
\text { deficit, high \% of services, high } \\
\text { unemployment rate }\end{array}$ \\
\hline$\#$ & $\begin{array}{l}\text { Brazil } \\
\text { Turkey }\end{array}$ & $\begin{array}{l}\text { Average-high GDP/capita } \\
\text { High unemployment rate } \\
\text { Average \% of services } \\
\text { Budget surplus, negative current } \\
\text { account balance, low savings } \\
\text { Average HDI }\end{array}$ & $\begin{array}{l}\text { Mexico } \\
\text { Russia } \\
\text { Turkey }\end{array}$ & $\begin{array}{l}\text { Average-high GDP/capita } \\
\text { High unemployment rate } \\
\text { Average \% of services } \\
\text { Sustainable public debt } \\
\text { Low savings } \\
\text { Average HDI }\end{array}$ \\
\hline$\# 4$ & $\begin{array}{l}\text { China } \\
\text { India } \\
\text { Indonesia }\end{array}$ & $\begin{array}{l}\text { Low GDP/capita } \\
\text { Low \% of services } \\
\text { High savings } \\
\text { High investments } \\
\text { Low HDI }\end{array}$ & China & $\begin{array}{l}\text { High GCI, low HDI, high savings } \\
\text { and investments, positive current } \\
\text { account balance, budget deficit, } \\
\text { sustainable public debt, low \% of } \\
\text { services, low unemployment, } \\
\text { relatively low GDP/capita }\end{array}$ \\
\hline$\# 5$ & Argentina & $\begin{array}{l}\text { Very low GCI, high HDI, low \% of } \\
\text { investments, low \% of savings, } \\
\text { negative current account balance, } \\
\text { budget deficit, } \\
\text { Sustainable public debt, } \\
\text { High \% of services, high } \\
\text { unemployment rate, high } \\
\text { GDP/capita }\end{array}$ & $\begin{array}{c}\text { India } \\
\text { Indonesia }\end{array}$ & $\begin{array}{l}\text { Low GDP/capita, } \\
\text { Low unemployment rate, } \\
\text { Low \% of services, } \\
\text { Budget deficit, negative current } \\
\text { balance, average-high } \\
\text { investments, average-high savings } \\
\text { Low HDI }\end{array}$ \\
\hline
\end{tabular}

Source: indicators and the results of the cluster analysis, k-means method.

The number of features highlighted in Table 9 also indicates the degree of homogeneity of clusters: the fewer the clusters the more heterogeneous they are, and vice versa. 


\section{Conclusions}

This investigation does not provide a hierarchy of countries according to their capacity to implement the 2030 Agenda; nevertheless it highlights that all E9 are fit to achieve the SDGs, taking into account a set of qualitative and quantitative indicators. Even if the SDGs are not legally binding, they have been included in national frameworks according to domestic socio-economic indicators. On one hand, these indicators offer an estimation of a specific country's ability to implement the SDGs, while on the other hand, they reflect particular needs. As a limitation of the paper, it should be mentioned that more research is needed on whether institutional requirements (as a sufficient condition) can also be met.

Taking into account the GDP/capita indicator, Saudi Arabia and Argentina are the best-ranked countries among the nine economies analysed, followed by Russia, Turkey, Brazil, Mexico, and China, while the disadvantaged countries are India and Indonesia. The unemployment rate also highlights contrasts: countries with low rates, such as Mexico, India, Indonesia, China, Russia, Saudi Arabia, and countries with high rates, Argentina, Brazil, and Turkey. Although in some countries, such as India, there was a gradual decline in the unemployment rate, this indicator is distorted by the fact that, based on social aid schemes, a large proportion of the population is considered to be employed, not socially assisted.

Regarding the structure of the economy, it is noted that the service sector generates the largest share in the added value in GDP; only in India and Indonesia was its level lower than 50\%. This situation is explained by the still significant share of agriculture in the economy, at 13\% in Indonesia and 15\% in India. Significant increases in the role of the tertiary sector in the economy are highlighted in countries such as Saudi Arabia, China, and Brazil, along with the decline in the share of the industrial sector.

In terms of public debt, an overview of the situation of the nine countries at selected time points highlights that only two countries recorded a level above 60\% of GDP in 2017 (Brazil 84\% of GDP and India $71 \%$ of GDP). There was a dramatic decrease in Saudi Arabia's debt, from almost 100\% of GDP in 2002 , to $17 \%$ of GDP in 2017, and to a lesser extent in the case of Russia (from 37\% to $16 \%$ in 2002-2017). At the same time, the recovery of Argentina, the sustainable level reached by Indonesia and Turkey (which halved their public debt over the past 15 years to less than $30 \%$ of GDP), and the increase in the public debt of China and Mexico, but without exceeding $60 \%$ of GDP are of note. In 2007, none of the countries included in the analysis had a budget deficit, but 10 years later, only Mexico was still reporting a surplus. Of the eight countries recording a deficit in 2017, only Saudi Arabia and Argentina exceeded the 3\% threshold, with Saudi Arabia being the most affected by the unfavourable evolution of oil prices. In 2017, six of the nine countries included in the study had a current account deficit, with some of them, such as Argentina and Turkey, registering a somewhat higher one (about $5 \%$ of GDP). Russia, Saudi Arabia, and China continue to register surpluses, although lower than in previous years.

Notable contrasts among the countries included in the study are also highlighted regarding the role of investments and savings. Thus, investments have a higher share of GDP in China, Indonesia, Turkey, India, and Saudi Arabia; in four of these countries the role of savings is also major (China, Indonesia, Saudi Arabia and India, in this order).

The Global Competitiveness Index reveals that, in the E9 group in 2017, the most competitive economy was China, followed by Saudi Arabia. A remarkable evolution in the last 15 years as that of Indonesia, the third among the nine E9 states. In contrast is the economy of Mexico, which was the third in the group in 2002, but only the sixth in 2017, and the economy of Brazil, in fourth place in 2002, but ranking penultimate in 2017. These countries have both lost competitiveness in recent years. Instead, the human development index reveals Saudi Arabia, Argentina, and Russia in the top three positions between the emerging countries analysed, while China, Indonesia, and India are ranked on the last positions.

It can be noted that, according to the trends indicated by the cluster analysis (hierarchical method), the intermediate moments $(2007,2012)$ were of transition from an initial situation (2002) characterized by some particular aspects to the different current status characterizing E9 economies. Throughout the 
period, one can note a closeness of the socio-economic characteristics between Argentina and Brazil and also between India and Indonesia, the "migration" of Mexico towards Russia and Turkey (forming the most heterogeneous group), and the two "islands" that differ from the group, Saudi Arabia and China.

Correlation testing for 2017 underlined the following: (1) there were strong associations between the competitiveness index, on one hand, and the shares of gross national savings, budget balance, and current account balance in GDP on the other; (2) there was very strong relationship between HDI and the value of GDP per capita; (3) there was a strong direct association between GDP per capita and budget balance, in addition to the current account balance as a share of GDP; (4)there was a direct relationship between the share of investments and gross national savings in GDP, and a very strong relationship between the budget balance and the current account balance as shares of GDP; (5) there were indirect relationships between the shares of services in GDP and the share of gross national savings in GDP, respectively, and between the current account balance and the share of public debt in GDP.

For the nine emerging economies, the less encouraging results recorded in some indicators are offset by favourable outcomes in others and/or by an advance in terms of qualitative indicators. Moreover, all nine countries analysed are engaged in global efforts towards sustainable development and have already adopted national strategies in order to implement the 2030 Agenda. At the same time, political will is just as important as the ability to achieve the 17 sustainable development goals, as the SDGs are not legally binding. All the nine countries included in this analysis have created national frameworks in order to meet these goals. There are too many aspects to take into account in order to define good institutions. The degree of SDG achievement in itself might be a good criterion in the future. Their socio-economic situations differ considerably, as reflected by various qualitative and quantitative indicators; therefore, these national frameworks are different. As this investigation does not correlate specific SDG frameworks with national socio-economic indicators, future studies should focus on such correlations. Moreover, each of the chosen indicators should be weighted so that a ranking of the emerging economies can be obtained according to their ability to implement the SDGs.

Author Contributions: This paper was a group effort, as follows: conceptualization, D.B. and I.M.O.S.; methodology, I.M.O.S; software, D.B.; validation, D.B., formal analysis, C.P., D.P., O.S., D.B., I.M.O.S., M.C.I., A.L.K.; investigation, D.B.; resources, D.B.; data curation, D.B.; writing—original draft preparation, D.B., I.M.O.S; writing-review and editing, M.C.I.; visualization, M.C.I.; supervision, C.P., D.P., O.S.; project administration, C.P., D.P., O.S.; funding acquisition, C.P.

Funding: This research was funded by the Romanian Ministry of Innovation and Research, grant PFE 24/16.10.2018, "Increasing research capacity in the economic field through the development of transdisciplinary research infrastructures (CERTRAN)".

Conflicts of Interest: The authors declare no conflict of interest. 


\section{Appendix A}

Table A1. Matrix representing the Pearson correlations between the selected indicators in 2002.

\begin{tabular}{|c|c|c|c|c|c|c|c|c|c|c|}
\hline Indicators & GCI & HDI & GDP/Capita & Investments/GDP & Saving Rate & $\begin{array}{c}\text { Unemployment } \\
\text { Rate }\end{array}$ & $\begin{array}{c}\text { Budget } \\
\text { Balance/GDP }\end{array}$ & $\begin{array}{c}\text { Public } \\
\text { Debt/GDP }\end{array}$ & $\begin{array}{c}\text { Current } \\
\text { Account/GDP }\end{array}$ & $\begin{array}{c}\text { \% Services } \\
\text { in GDP }\end{array}$ \\
\hline GCI & 1.00 & -0.16 & -0.08 & 0.83 & 0.90 & -0.63 & -0.24 & -0.52 & 0.66 & -0.57 \\
\hline HDI & -0.16 & 1.00 & 0.93 & -0.34 & -0.23 & 0.30 & -0.42 & -0.46 & 0.14 & 0.48 \\
\hline GDP/capita & -0.08 & 0.93 & 1.00 & -0.30 & -0.18 & 0.26 & -0.69 & -0.38 & 0.22 & 0.37 \\
\hline Investments/GDP & 0.83 & -0.34 & -0.30 & 1.00 & 0.96 & -0.49 & -0.07 & -0.35 & 0.20 & -0.71 \\
\hline Saving rate & 0.90 & -0.23 & -0.18 & 0.96 & 1.00 & -0.55 & -0.20 & -0.39 & 0.44 & -0.65 \\
\hline Unemployment rate & -0.63 & 0.30 & 0.26 & -0.49 & -0.55 & 1.00 & -0.04 & 0.30 & -0.38 & 0.50 \\
\hline Budget balance/GDP & -0.24 & -0.42 & -0.69 & -0.07 & -0.20 & -0.04 & 1.00 & 0.28 & -0.34 & 0.21 \\
\hline Public debt/GDP & -0.52 & -0.46 & -0.38 & -0.35 & -0.39 & 0.30 & 0.28 & 1.00 & -0.28 & 0.41 \\
\hline Current account/GDP & 0.66 & 0.14 & 0.22 & 0.20 & 0.44 & -0.38 & -0.34 & -0.28 & 1.00 & 0.00 \\
\hline \% services in GDP & -0.57 & 0.48 & 0.37 & -0.71 & -0.65 & 0.50 & 0.21 & 0.41 & 0.00 & 1.00 \\
\hline
\end{tabular}
Source: Table developed by authors based on calculations computed with Statistica software. Note: GCI—Global Competitiveness Index, HDI—Human Development Index, GDP—Gross
Domestic Product.

Table A2. Matrix representing the Pearson correlations between the selected indicators in 2007.

\begin{tabular}{|c|c|c|c|c|c|c|c|c|c|c|}
\hline Indicators & GCI & HDI & GDP/Capita & Investments/GDP & Saving Rate & $\begin{array}{c}\text { Unemployment } \\
\text { Rate }\end{array}$ & $\begin{array}{c}\text { Budget } \\
\text { Balance/GDP }\end{array}$ & $\begin{array}{c}\text { Public } \\
\text { Debt/GDP }\end{array}$ & $\begin{array}{c}\text { Current } \\
\text { Account/GDP }\end{array}$ & $\begin{array}{c}\text { \% Services } \\
\text { in GDP }\end{array}$ \\
\hline GCI & 1.00 & -0.17 & 0.15 & 0.55 & 0.82 & -0.58 & 0.41 & -0.48 & 0.68 & -0.52 \\
\hline HDI & -0.17 & 1.00 & 0.80 & -0.70 & -0.11 & 0.27 & 0.59 & -0.47 & 0.39 & 0.22 \\
\hline GDP/capita & 0.15 & 0.80 & 1.00 & -0.55 & 0.07 & 0.13 & 0.86 & -0.49 & 0.50 & 0.06 \\
\hline Investments/GDP & 0.55 & -0.70 & -0.55 & 1.00 & 0.69 & -0.55 & -0.33 & 0.00 & 0.11 & -0.51 \\
\hline Saving rate & 0.82 & -0.11 & 0.07 & 0.69 & 1.00 & -0.59 & 0.34 & -0.34 & 0.78 & -0.73 \\
\hline Unemployment rate & -0.58 & 0.27 & 0.13 & -0.55 & -0.59 & 1.00 & 0.10 & 0.13 & -0.29 & 0.18 \\
\hline Budget balance/GDP & 0.41 & 0.59 & 0.86 & -0.33 & 0.34 & 0.10 & 1.00 & -0.55 & 0.74 & -0.34 \\
\hline Public debt/GDP & -0.48 & -0.47 & -0.49 & 0.00 & -0.34 & 0.13 & -0.55 & 1.00 & -0.54 & 0.25 \\
\hline Current account/GDP & 0.68 & 0.39 & 0.50 & 0.11 & 0.78 & -0.29 & 0.74 & -0.54 & 1.00 & -0.69 \\
\hline \% services in GDP & -0.52 & 0.22 & 0.06 & -0.51 & -0.73 & 0.18 & -0.34 & 0.25 & -0.69 & 1.00 \\
\hline
\end{tabular}

Source: Table developed by authors based on calculations computed with Statistica software. 
Table A3. Matrix representing the Pearson correlations between the selected indicators in 2012.

\begin{tabular}{|c|c|c|c|c|c|c|c|c|c|c|}
\hline Indicators & GCI & HDI & GDP/Capita & Investments/GDP & Saving Rate & $\begin{array}{c}\text { Unemployment } \\
\text { Rate }\end{array}$ & $\begin{array}{c}\text { Budget } \\
\text { Balance/GDP }\end{array}$ & $\begin{array}{c}\text { Public } \\
\text { Debt/GDP }\end{array}$ & $\begin{array}{c}\text { Current } \\
\text { Account/GDP }\end{array}$ & $\begin{array}{c}\text { \% Services } \\
\text { in GDP }\end{array}$ \\
\hline GCI & 1.00 & -0.01 & 0.42 & 0.31 & 0.36 & -0.46 & -0.38 & -0.12 & -0.09 & -0.16 \\
\hline HDI & -0.01 & 1.00 & 0.63 & -0.66 & -0.40 & 0.49 & 0.39 & 0.32 & 0.40 & 0.56 \\
\hline GDP/capita & 0.42 & 0.63 & 1.00 & -0.33 & -0.28 & -0.16 & -0.06 & 0.10 & -0.01 & 0.30 \\
\hline Investments/GDP & 0.31 & -0.66 & -0.33 & 1.00 & 0.84 & -0.69 & -0.33 & -0.73 & -0.29 & -0.58 \\
\hline Saving rate & 0.36 & -0.40 & -0.28 & 0.84 & 1.00 & -0.42 & -0.55 & -0.51 & 0.23 & -0.65 \\
\hline Unemployment rate & -0.46 & 0.49 & -0.16 & -0.69 & -0.42 & 1.00 & 0.25 & 0.77 & 0.44 & 0.33 \\
\hline Budget balance/GDP & -0.38 & 0.39 & -0.06 & -0.33 & -0.55 & 0.25 & 1.00 & -0.08 & -0.27 & 0.53 \\
\hline Public debt/GDP & -0.12 & 0.32 & 0.10 & -0.73 & -0.51 & 0.77 & -0.08 & 1.00 & 0.38 & 0.07 \\
\hline Current account/GDP & -0.09 & 0.40 & -0.01 & -0.29 & 0.23 & 0.44 & -0.27 & 0.38 & 1.00 & -0.30 \\
\hline \% services in GDP & -0.16 & 0.56 & 0.30 & -0.58 & -0.65 & 0.33 & 0.53 & 0.07 & -0.30 & 1.00 \\
\hline
\end{tabular}

Source: Table developed by authors based on calculations computed with Statistica software.

Table A4. Matrix representing the Pearson correlations between the selected indicators in 2017.

\begin{tabular}{|c|c|c|c|c|c|c|c|c|c|c|}
\hline Indicators & GCI & HDI & GDP/Capita & Investments/GDP & Saving Rate & $\begin{array}{c}\text { Unemployment } \\
\text { Rate }\end{array}$ & $\begin{array}{c}\text { Budget } \\
\text { Balance/GDP }\end{array}$ & $\begin{array}{c}\text { Public } \\
\text { Debt/GDP }\end{array}$ & $\begin{array}{c}\text { Current } \\
\text { Account/GDP }\end{array}$ & $\begin{array}{c}\text { \% Services } \\
\text { in GDP }\end{array}$ \\
\hline GCI & 1.00 & 0.11 & 0.36 & 0.45 & 0.83 & -0.24 & 0.78 & -0.41 & 0.71 & -0.65 \\
\hline HDI & 0.11 & 1.00 & 0.90 & -0.64 & -0.09 & 0.57 & 0.57 & -0.64 & 0.58 & 0.11 \\
\hline GDP/capita & 0.36 & 0.90 & 1.00 & -0.59 & 0.09 & 0.46 & 0.83 & -0.62 & 0.79 & -0.11 \\
\hline Investments/GDP & 0.45 & -0.64 & -0.59 & 1.00 & 0.72 & -0.65 & 0.16 & 0.08 & -0.07 & -0.51 \\
\hline Saving rate & 0.83 & -0.09 & 0.09 & 0.72 & 1.00 & -0.58 & 0.50 & -0.42 & 0.64 & -0.82 \\
\hline Unemployment rate & -0.24 & 0.57 & 0.46 & -0.65 & -0.58 & 1.00 & 0.14 & -0.03 & -0.11 & 0.45 \\
\hline Budget balance/GDP & 0.78 & 0.57 & 0.83 & -0.16 & 0.50 & 0.14 & 1.00 & -0.62 & 0.90 & -0.51 \\
\hline Public debt/GDP & -0.41 & -0.64 & -0.62 & 0.08 & -0.42 & -0.03 & -0.62 & 1.00 & -0.69 & 0.48 \\
\hline Current account/GDP & 0.71 & 0.58 & 0.79 & -0.07 & 0.64 & -0.11 & 0.90 & -0.69 & 1.00 & -0.61 \\
\hline \% services in GDP & -0.65 & 0.11 & -0.11 & -0.51 & -0.82 & 0.45 & -0.51 & 0.48 & -0.61 & 1.00 \\
\hline
\end{tabular}

Source: Table developed by authors based on calculations computed with Statistica software. 


\section{Appendix B}

2002

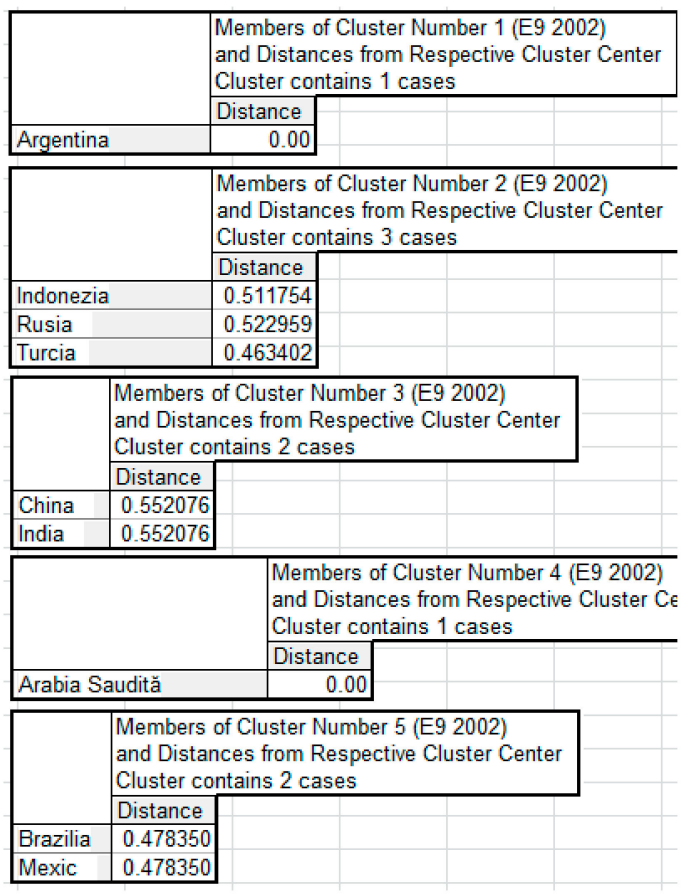

2012

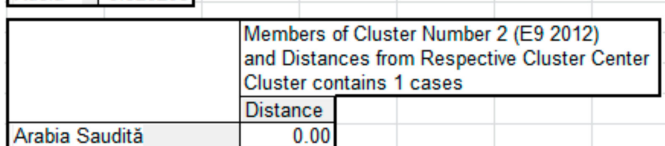

\begin{tabular}{ll} 
Arabia Saudită & 0.00 \\
\hline
\end{tabular}

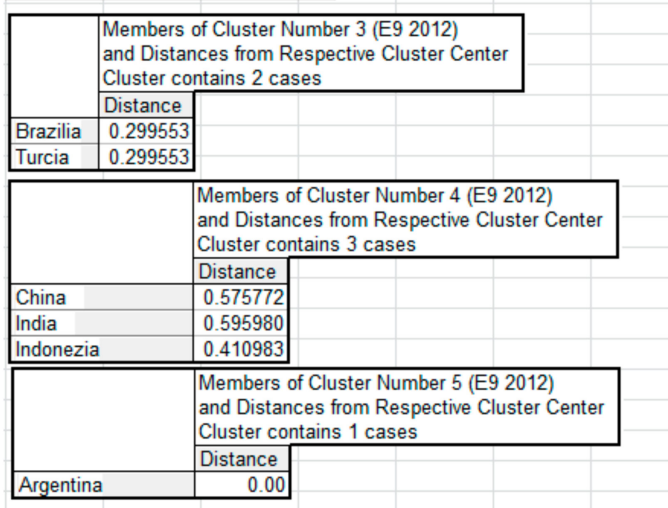

2007

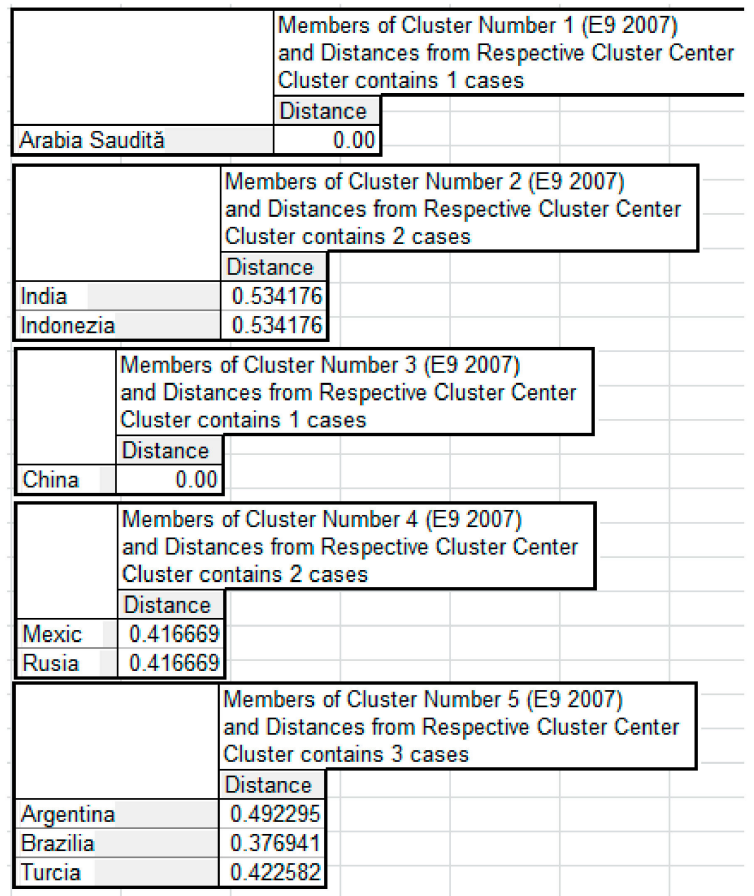

2017

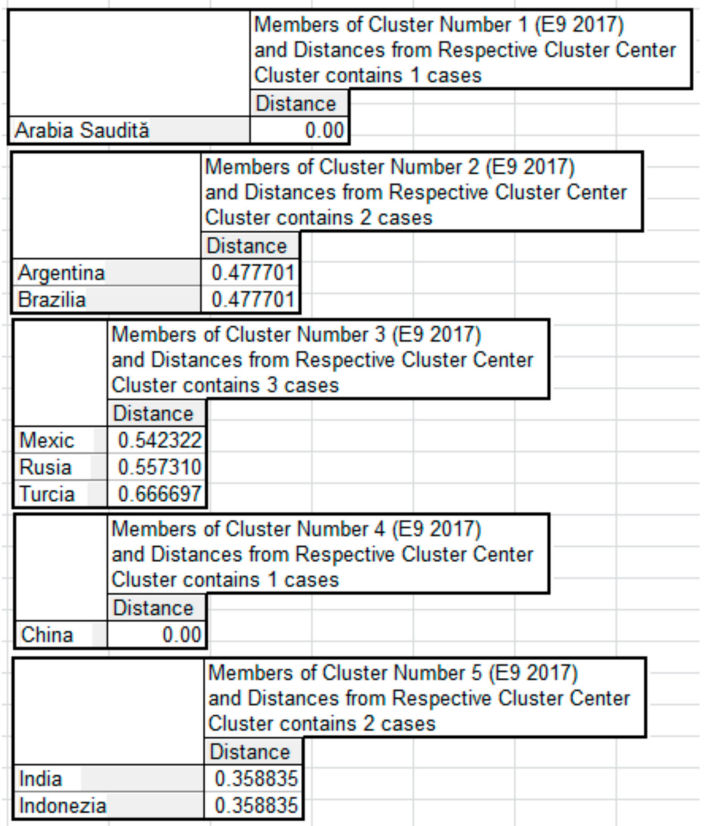

Figure A1. Intra-cluster distances, k-means method. Source: Figures developed by authors based on the results obtained by using Statistica software.

\section{References}

1. Giddings, B.; Hopwood, B.; O’Brien, G. Environment, economy and society: Fitting them together into sustainable development. Sustain. Dev. 2002, 10, 187-196. [CrossRef]

2. The Organisation for Economic Co-operation and Development (OECD). Sustainable Development: Linking Economy, Society, Environment; The Organisation for Economic Co-Operation and Development: Paris, France, December 2008. 
3. Martine, G.; Diniz Alves, J.E. Economy, society and environment in the 21st century: Three pillars or trilemma of sustainability? Rev. Bras. Estud. Popul. 2015, 32, 433-460. [CrossRef]

4. United Nations. The Sustainable Development Goals Report 2018; United Nations: New York, NY, USA, 2018.

5. Koch, F.; Krellenberg, K. How to Contextualize SDG 11? Looking at Indicators for Sustainable Urban Development in Germany. ISPRS Int. J. Geo-Inf. 2018, 7, 464. [CrossRef]

6. Sachs, J.; Schmidt-Traub, G.; Kroll, C.; Lafortune, G.; Fuller, G. SDG Index and Dashboards Report 2018: Global Responsibilities, Implementing the Goals; Bertelsmann Stiftung and Sustainable Development Solutions Network (SDSN); Pica Publishing Ltd.: New York, NY, USA, 2018.

7. United Nations. Sustainable Development Knowledge Platform-Voluntary National Reviews Database. 2019. Available online: https://sustainabledevelopment.un.org/memberstates (accessed on 25 April 2019).

8. World Resources Institute. CAIT Climate Data Explorer. 2018. Available online: http://cait.wri.org/ (accessed on 3 December 2018).

9. World Commission on Environment and Development (WCED). Report of the World Commission on Environment and Development: Our Common Future. 1987. Available online: http://www.un-documents. net/our-common-future.pdf (accessed on 28 February 2019).

10. Kates, R.W.; Parris, T.M.; Leiserowitz, A.A. What Is Sustainable Development Goals, Indicators, Values, and Practice. Environ. Sci. Policy Sustain. Dev. 2005, 47, 8-21.

11. Lucci, P.; Khan, A.; Stuart, E. Means of Implementation and the Global Partnership for Sustainable Development: What's in It for the Emergent Economies? ODI Annual Reports. May 2015. Available online: https: //www.odi.org/sites/odi.org.uk/files/odi-assets/publications-opinion-files/9654.pdf (accessed on 28 February 2019).

12. Kulkarni, S. The Huge Potential Role of BRICS in Achieving the 2030 Agenda. 2018. Available online: https://impakter.com/huge-potential-role-brics-achieving-2030-agenda/ (accessed on 28 February 2019).

13. Ali, S.; Hussain, T.; Zhang, G.; Nurunnabi, M.; Li, B. The Implementation of Sustainable Development Goals in "BRICS" Countries. Sustainability 2018, 10, 2513. [CrossRef]

14. Moagăr-Poladian, S. The Global Economy in a Significant Transforming Process of the Power Centers. J. Glob. Econ. 2010. Available online: http://oaji.net/articles/2016/3365-1467891834.pdf (accessed on 1 March 2019).

15. Ghibuţiu, A.; Moagăr-Poladian, S. Global Sourcing of Services: How Well Are The New EU Member States Coping With The Challenges? (Part II). Rom. J. Econ. Forecast. 2009, 2, 184-199.

16. Hackenesch, C.; Janus, H. Post 2015: How Emerging Economies Shape the Relevance of a New Agenda, German Development Institute, Briefing Paper 14/2013. Available online: http:/edoc.vifapol.de/opus/ volltexte/2013/4598/pdf/BP_14.2013.pdf (accessed on 1 March 2019).

17. Williamson, O.E. Markets and Hierarchies, Analysis and Antitrust Implications: A Study in the Economics of Internal Organization; The Free Press: New York, NY, USA, 1975.

18. North, D. Institutions, Institutional Change and Economic Performances; Cambridge University Press: Cambridge, UK, 1990.

19. Acemoglu, D.; Johnson, S.; Robinson, J.A. Institutions as a Fundamental Cause of Long-Run Growth. In Handbook of Growth Economics; Aghion, P., Durlauf, S., Eds.; Elsevier: North Holland, The Netherlands, 2005; Volume 1A.

20. Acemoglu, D.; Johnson, S.; Robinson, J.A. Why Nations Fail-The Origins of Power, Prosperity and Poverty, Crown Business; Random House: New York, NY, USA, 2012.

21. World Economic Forum. The Global Competitiveness Report 2018-2019; World Economic Forum: Geneva, Switzerland, 2018.

22. United Nations Development Program. Human Development Index. 2018. Available online: http: //hdr.undp.org/en/content/human-development-index-hdi (accessed on 11 October 2018).

23. World Economic Forum. The Global Competitiveness Report 2002-2003; World Economic Forum: Geneva, Switzerland, 2002.

24. World Economic Forum. The Global Competitiveness Report 2007-2008; World Economic Forum: Geneva, Switzerland, 2007.

25. World Economic Forum. The Global Competitiveness Report 2012-2013; World Economic Forum: Geneva, Switzerland, 2012.

26. World Economic Forum. The Global Competitiveness Report 2017-2018; World Economic Forum: Geneva, Switzerland, 2017. 
27. International Monetary Fund (IMF). World Economic Outlook Database. 2018. Available online: https: //www.imf.org/external/pubs/ft/weo/2018/02/weodata/index.aspx (accessed on 3 October 2018).

28. The World Bank. World Development Indicators. 2018. Available online: http://databank.worldbank.org/ data/home.aspx (accessed on 8 October 2018).

29. Malik, K.; Jasińska-Biliczak, A. Innovations and Other Processes as Identifiers of Contemporary Trends in the Sustainable Development of SMEs: The Case of Emerging Regional Economies. Sustainability 2018, 10, 1361. [CrossRef]

30. Nagy, J.A.; Benedek, J.; Ivan, K. Measuring Sustainable Development Goals at a Local Level: A Case of a Metropolitan Area in Romania. Sustainability 2018, 10, 3962. [CrossRef]

31. Villeneuve, C.; Tremblay, D.; Riffon, O.; Lanmafankpotin, G.Y.; Bouchard, S. A Systemic Tool and Process for Sustainability Assessment. Sustainability 2017, 9, 1909. [CrossRef]

32. Janoušková, S.; Hák, T.; Moldan, B. Global SDGs Assessments: Helping or Confusing Indicators? Sustainability 2018, 10, 1540. [CrossRef]

33. Kroll, C. SDGs: Are the Rich Countries Ready? Bertelsmann Stiftung: Gütersloh, Germany, 2015.

34. Sachs, J.; Schmidt-Traub, G.; Kroll, C.; Durand-Delacre, D.; Teksoz, K. SDG Index and Dashboards Report 2017: International Spillovers in Achieving the Goals; Bertelsmann Stiftung and Sustainable Development Solutions Network: Paris, France; New York, NY, USA, 2017.

35. Eurostat. Sustainable Development in the European Union-Monitoring Report on Progress towards the SDGs in an EU Context; Eurostat: Luxembourg, 2017.

36. Oehler-Şincai, I.M.; Bulin, D.; Dobre, R.I.; Dumitrescu, A.L.; Dumitrescu, G.C. The Increasing Regional and Global Role of India. Implications for Global Value Chains, Institute for World Economy; Romanian Academy: Bucharest, Romania, November 2018.

(C) 2019 by the authors. Licensee MDPI, Basel, Switzerland. This article is an open access article distributed under the terms and conditions of the Creative Commons Attribution (CC BY) license (http://creativecommons.org/licenses/by/4.0/). 